\title{
AIRBORNE ELECTROMAGNETIC AND MAGNETIC SURVEY, WESTERNYUKON FLATS, INTERIOR ALASKA
}

Emond, A.M., Minsley, B.J., Daanen, R.P., Graham, G.R.C., and CGG

Geophysical Report 2016-2

December 2018

STATE OF ALASKA

DEPARTMENT OF NATURAL RESOURCES

DIVISION OF GEOLOGICAL \& GEOPHYSICAL SURVEYS
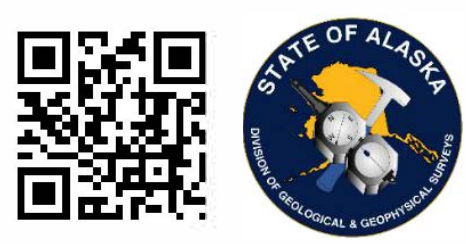
STATE OF ALASKA

Michael J. Dunleavy, Governor

\section{DEPARTMENT OF NATURAL RESOURCES}

Corri A. Feige, Commissioner

\section{DIVISION OF GEOLOGICAL \& GEOPHYSICAL SURVEYS}

Steve Masterman, State Geologist \& Director

Publications produced by the Division of Geological \& Geophysical Surveys are availableto download from the DGGS website (dqgs.alaska.gov). Publications on hard-copy or digital media can beexamined or purchased in the Fairbanks office:

\section{Alaska Division of Geological \& Geophysical Surveys (DGGS)}

3354 College Road | Fairbanks, Alaska 99709-3707

Phone: 907.451 .5010 | Fax 907.451.5050

dggspubs@alaska.gov | dggs.alaska.gov

DGGS publications are also available at:

Alaska State Library, Historical

Collections \& Talking Book Center

395 Whittier Street

Juneau, Alaska 99801

Alaska Resource Library and

Information Services (ARLIS)

3150 C Street, Suite 100

Anchorage, Alaska 99503

\section{Suggested citation:}

Emond, A.M., Minsley, BJ., Daanen, R.P., Graham, G.R.C., and CGG, 2018, Airborne electromagnetic and magnetic survey, Western Yukon Flats, interior Alaska: Alaska Division of Geological \& Geophysical Surveys Geophysical Report 2016-2.

http://doi.org/10.14509/29683
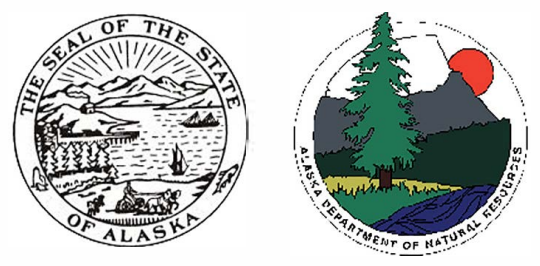


\title{
AIRBORNE ELECTROMAGNETIC AND MAGNETIC SURVEY, WESTERN YUKON FLATS, INTERIOR ALASKA \\ Emond, A.M., ${ }^{1}$ Minsley, B.J., ${ }^{2}$ Daanen, R.P., ${ }^{1}$ Graham, G.R.C., ${ }^{1}$ and CGG
}

\begin{abstract}
Alaska Division of Geological \& Geophysical Surveys, in conjunction with the University of Alaska Fairbanks, Institute of Northern Engineering, Water and Environmental Research Center, managed the collection of frequency domain electromagnetic and magnetic data lines over a 200-square-kilometer portion of Western Yukon Flats, interior Alaska. Survey lines cover selected areas pertinent to the scope of research. The 301-line-kilometer survey was flown from February 25th to March 1st, 2016. Data were collected by CGG using the RESOLVE airborne geophysical survey system and measured $30 \mathrm{~m}$ above the ground surface from a helicopter-towed sensor platform ("bird") on a 30-m-long line.
\end{abstract}

\section{PURPOSE}

These geophysical data are part of the University of Alaska Fairbanks, Institute of Northern Engineering, Water and Environmental Research Center Goldstream Valley Watershed project, which aims to define processes within the hydrology-permafrost-methane system at the lake to watershed scale across the seasonal to millennial time scales. The data were collected to facilitate understanding of processes within a hydrologypermafrost-methane system in an area of discontinuous permafrost and thaw lakes in the sub-arctic region. Goldstream Valley and surrounding areas of Interior Alaska offer a convenient and data-rich study area for landscapes with discontinuous permafrost and thaw lakes in the sub-arctic region.

\section{SURVEY OVERVIEW DESCRIPTION}

This document provides an overview of the survey and includes text and figures of select primary and derivative products of this survey. A table of digital data packages available for download is provided to assist users in data selection. For reference a catalog of the available maps is presented in reduced resolution. Please consult the metadata, project report, and digital data packages for more information and data.

\footnotetext{
${ }^{1}$ Alaska Division of Geological \& Geophysical Surveys, 3354 College Road, Fairbanks, Alaska 99709-3707

${ }^{2}$ Geology, geophysics, and Geochemistry Science Center, U.S. Geological Survey, W $6{ }^{\text {th }}$ Ave., Kipling St., Lakewood, CO 80225
} 


\begin{tabular}{|c|c|c|}
\hline Data Type & Provider & Description \\
\hline ascii_data & contractor & ASCll format line data, other ASCII data \\
\hline databases_geosoft & contractor & $\begin{array}{l}\text { Geosoft format database of final line data, other } \\
\text { Geosoft format databases }\end{array}$ \\
\hline documents & contractor and DGGS & $\begin{array}{l}\text { Project and field reports, survey background } \\
\text { information, gridded data explanations, other } \\
\text { documentation }\end{array}$ \\
\hline grids_ermapper & contractor & $\begin{array}{l}\text { Geographically registered gridded data, ER Mapper } \\
\text { ERS format }\end{array}$ \\
\hline grids_geosoft & contractor and DGGS & $\begin{array}{l}\text { Geosoft-format binary grids, these grids can be } \\
\text { viewed in ESRI ArcMap using a free plugin from } \\
\text { Geosoft }\end{array}$ \\
\hline images_registered & DGGS & GeoTiff format images of all gridded data \\
\hline $\mathrm{kmz}$ & contractor & kml language kmz archive files of project data \\
\hline maps_pdf_format & contractor & Printable maps in pdf format \\
\hline maps_prn_format & contractor & $\begin{array}{l}\text { Printable maps in HPGL/G printer file format with } \\
\text { extension .prn }\end{array}$ \\
\hline resistivity_models & DGGS & $\begin{array}{l}\text { ACSII CSV format resistivity models in project } \\
\text { coordinates with data field guides, figures and } \\
\text { supporting documentation in ASCII text, PDF, KML, } \\
\text { and/or other formats }\end{array}$ \\
\hline vector_data & contractor and DGGS & $\begin{array}{l}\text { Line path, data contours, and survey boundary in } \\
\text { ESRI shape file (SHP) format }\end{array}$ \\
\hline video_flightpath & contractor & Survey flight path downward facing video \\
\hline
\end{tabular}

\section{ACKNOWLEDGMENTS}

The Goldstream Valley Watershed project is funded by the National Science Foundation, Office of Polar Programs, Arctic System Science Program, award \#1500931. 


\section{REFERENCES}

Ball, L.B., Smith, B.D., Minsley, B.J., Abraham, J.D., Voss, C.I., Astley, B.N., Deszcz-Pan, Maria, and Cannia, J.C., 2011, Airborne electromagnetic and magnetic geophysical survey data of the Yukon Flats and Fort Wainwright areas, central Alaska, June 2010: U.S. Geological Survey Open-File Report 2011-1304, 21 p. https://pubs.usgs.gov/of/2011/1304

Emond, A.M., Daanen, R.P., Graham, G.R.C., Walter Anthony, Katey, Liljedahl, A.K., Minsley, B.J., Barnes, D.L., Romanovsky, V.E., and CGG Canada Services Ltd., 2018, Airborne electromagnetic and magnetic survey, Goldstream Creek watershed, interior Alaska: Alaska Division of Geological \& Geophysical Surveys Geophysical Report 2016-5, 14 p. http://doi.org/10.14509/29681

Emond, A.M., Little, L.M., Graham, G.R.C., Minsley, B.J., and CGG, 2018, Airborne electromagnetic and magnetic survey, Yukon Crossing, interior Alaska: Alaska Division of Geological \& Geophysical Surveys Geophysical Report 2016-4. http://doi.org/10.14509/29682

Graham, G.R.C., Emond, A.M., Daanen, R.P., Minsley, B.J., and CGG, 2018, Airborne electromagnetic and magnetic survey, Yukon Crossing to Fox profile, interior Alaska: Alaska Division of Geological \& Geophysical Surveys Geophysical Report 2016-3. http://doi.org/10.14509/29684

Minsley, B.J., Emond, A.M., and Rey, D.M., 2017, Airborne electromagnetic and magnetic survey data and inverted resistivity models, western Yukon Flats, Alaska, February 2016, U.S. Geological Survey data release. https://doi.org/10.5066/F7QC01P9 

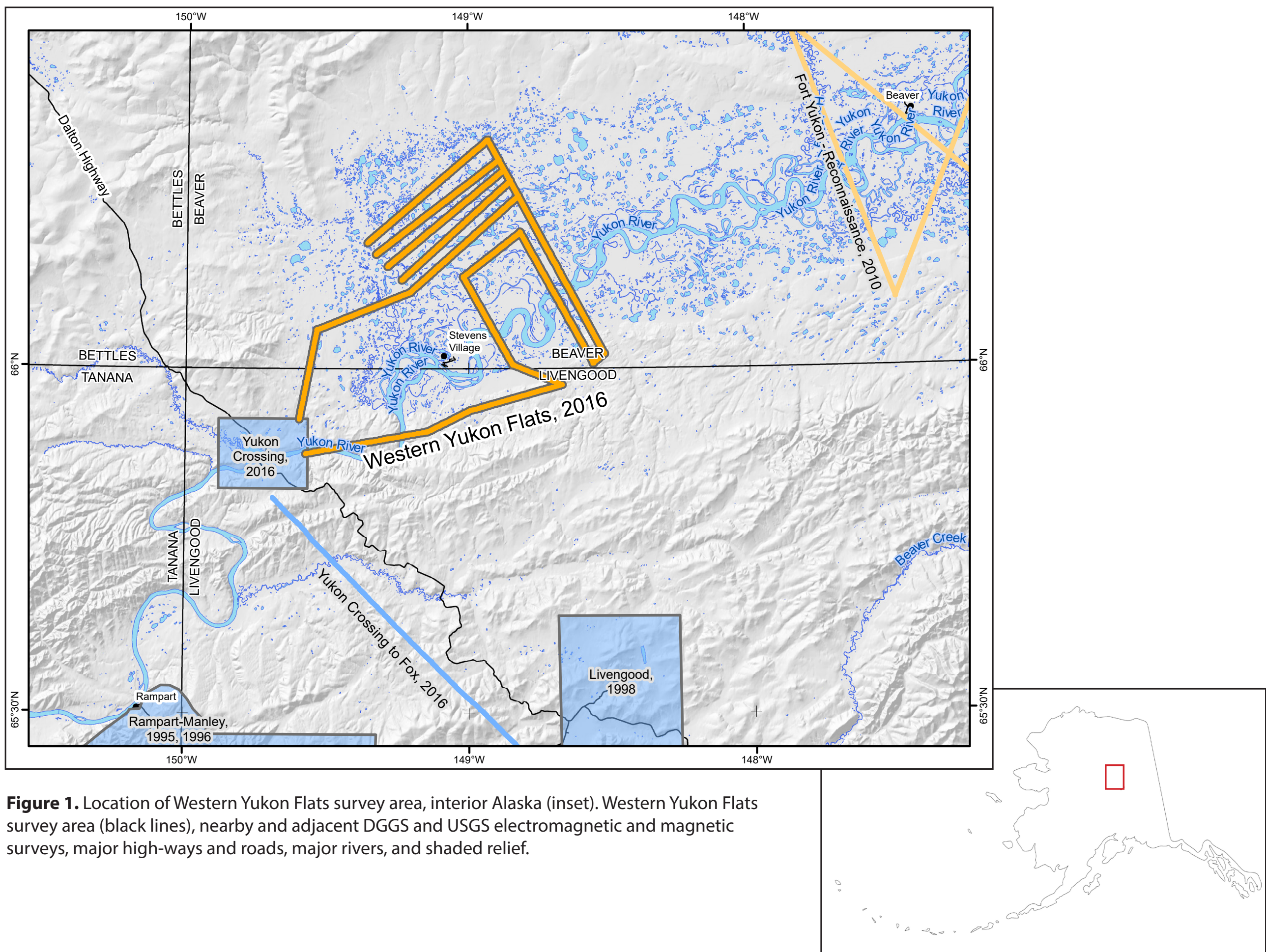

Figure 1. Location of Western Yukon Flats survey area, interior Alaska (inset). Western Yukon Flats survey area (black lines), nearby and adjacent DGGS and USGS electromagnetic and magnetic surveys, major high-ways and roads, major rivers, and shaded relief. 


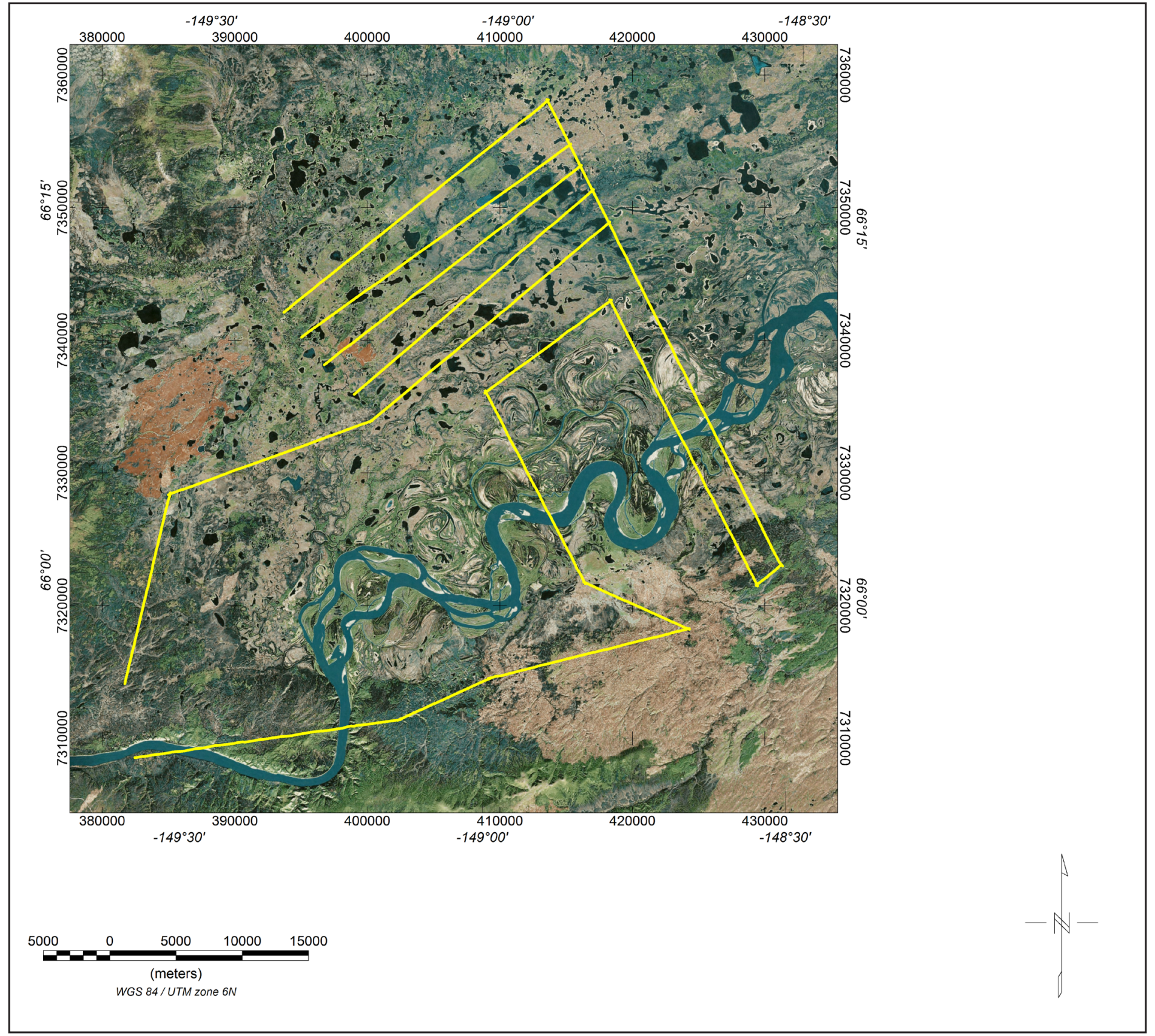

Figure 2. Paths of survey flight lines and wider-spaced perpendicular tie lines with orthophoto. 


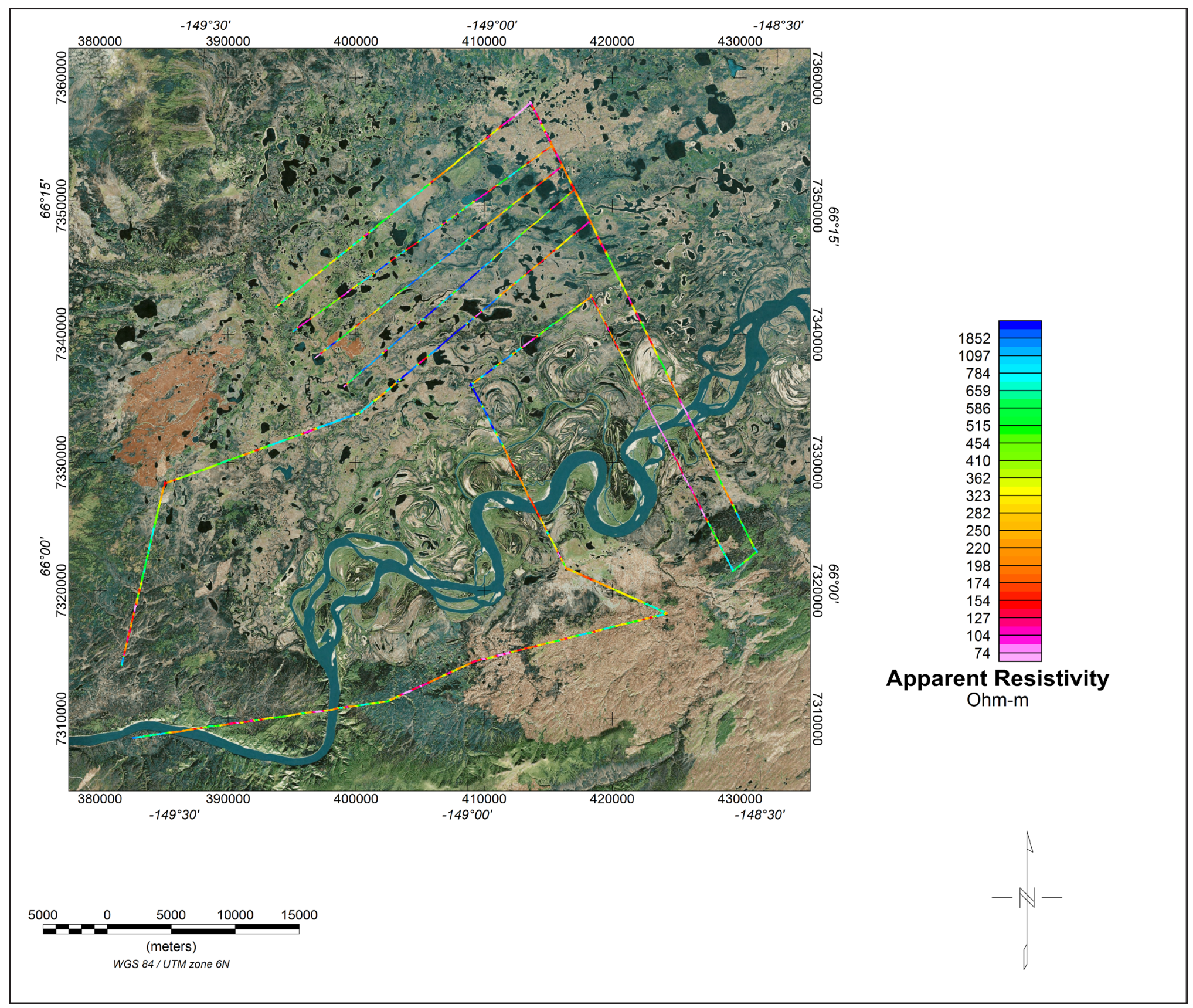

Figure 3. 8,200 Hz apparent resistivity grid and orthophoto. The RESOLVE EM system operates at six distinct frequencies, and measures the inphase and quadrature components at each frequency. Five coplanar coil pairs operate at 400, 1,800, 8,200 (shown), 40,000, and 140,000 Hz, and one coaxial coil pair operates at $3,300 \mathrm{~Hz}$. The EM data were sampled at 0.1 second intervals. The EM system responds to bedrock conductors, conductive overburden, and man-made cultural sources. Apparent resistivity is generated from the inphase and quadrature components for each frequency using the pseudo-layer half-space model. 


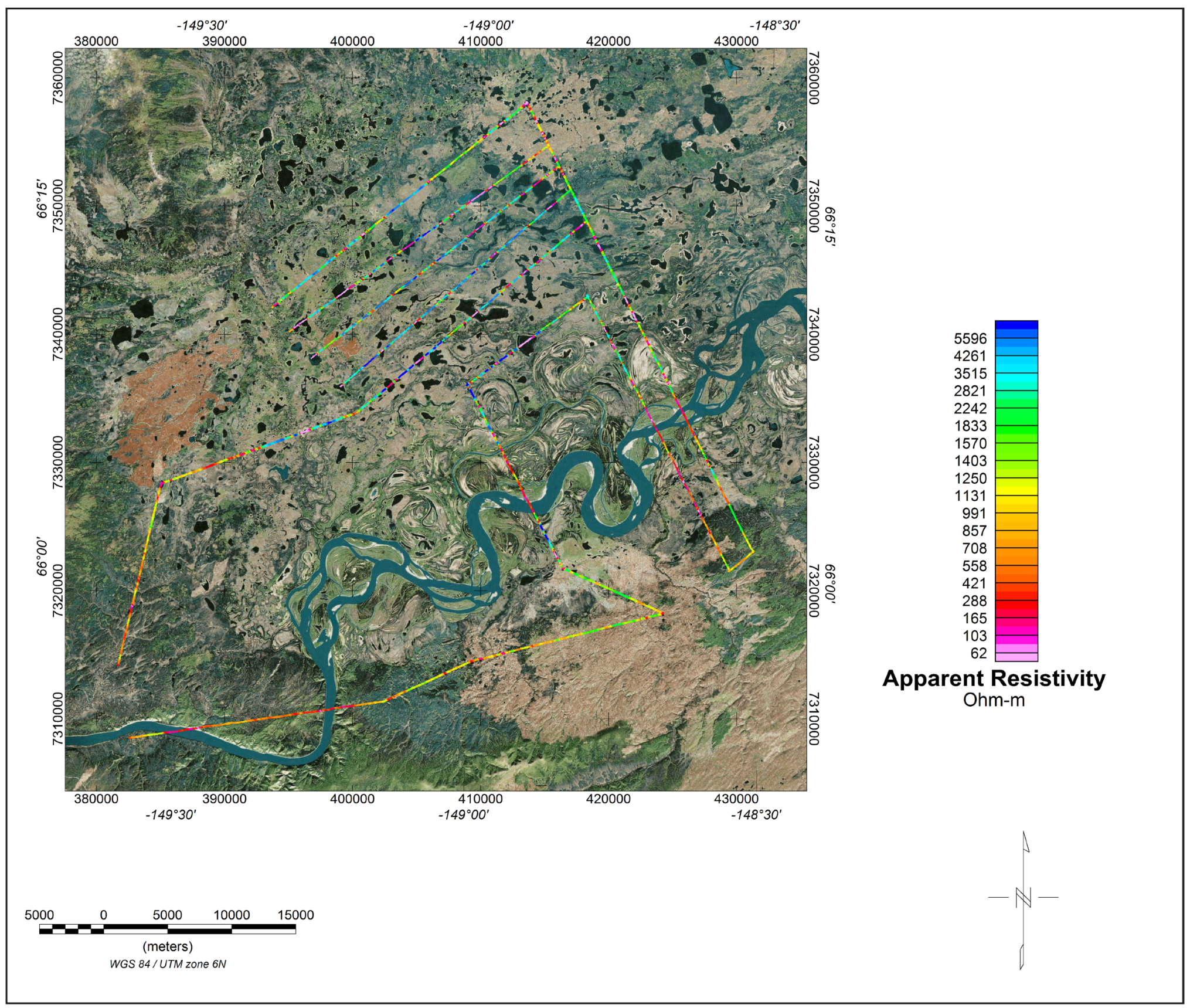

Figure 4. 140,000 hertz ( $\mathrm{Hz})$ apparent resistivity grid and orthophoto. The RESOLVE electromagnetic (EM) system operates at six distinct frequencies, and measures the inphase and quadrature components at each frequency. Five coplanar coil pairs operate at 400, 1,800, 8,200, 40,000, and 140,000 Hz (shown), and one coaxial coil pair operates at $3,300 \mathrm{~Hz}$. The EM data were sampled at 0.1 second intervals. The EM system responds to bedrock conductors, conductive overburden, and man-made cultural sources. Apparent resistivity is generated from the inphase and quadrature components for each frequency using the pseudo-layer half-space model. 


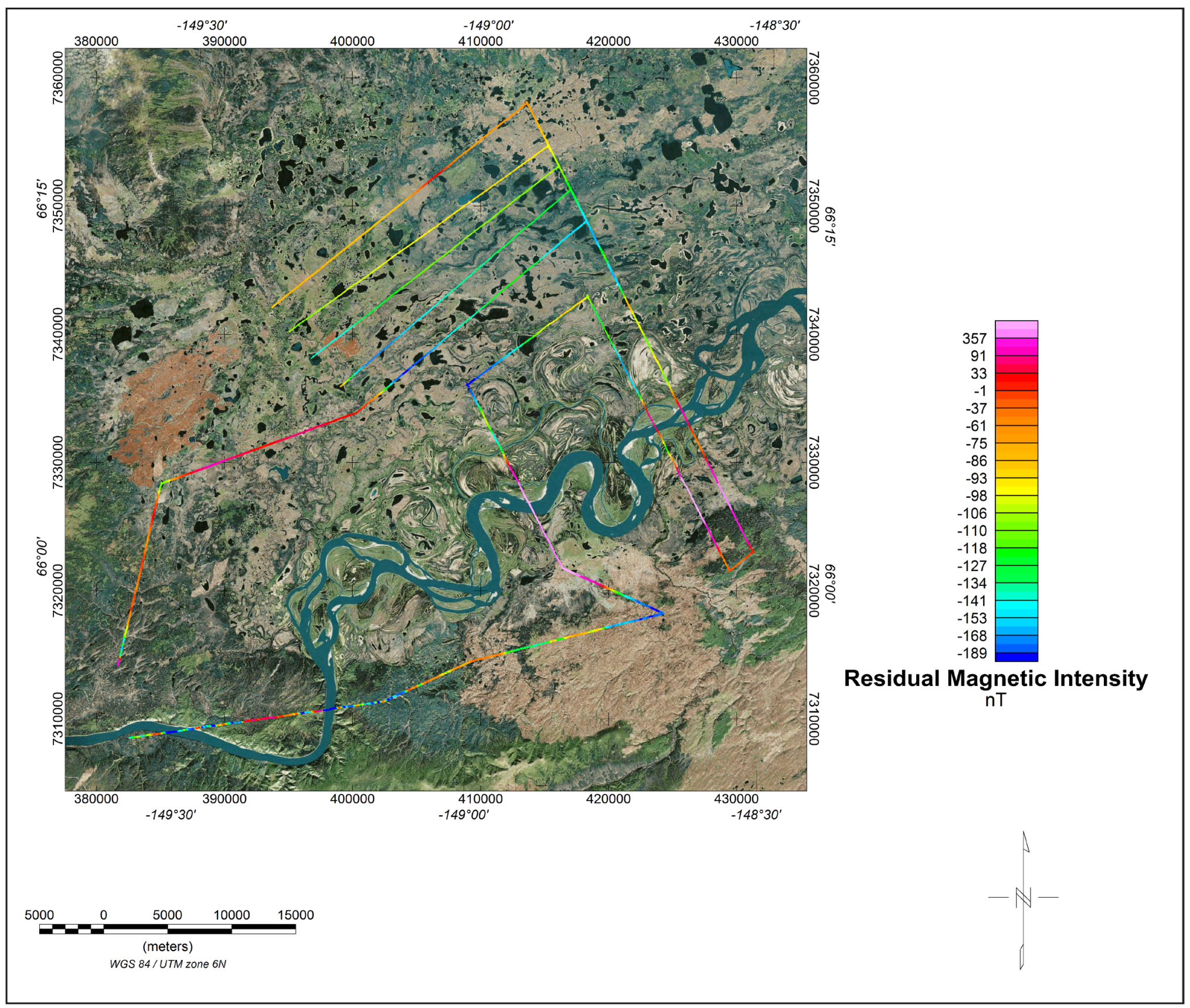

Figure 5. Residual magnetic intensity grid and orthophoto. The magnetic total field data were collected using a Scintrex CS3 cesium sensor at a sampling interval of 0.1 seconds and processed using digitally recorded data from a CGG D1344 base station magnetometer. The magnetic data were: (1) corrected for diurnal variations by subtraction of the base station magnetic data; (2) IGRF corrected (IGRF model 2010, updated for data of flight and altimeter variations). 


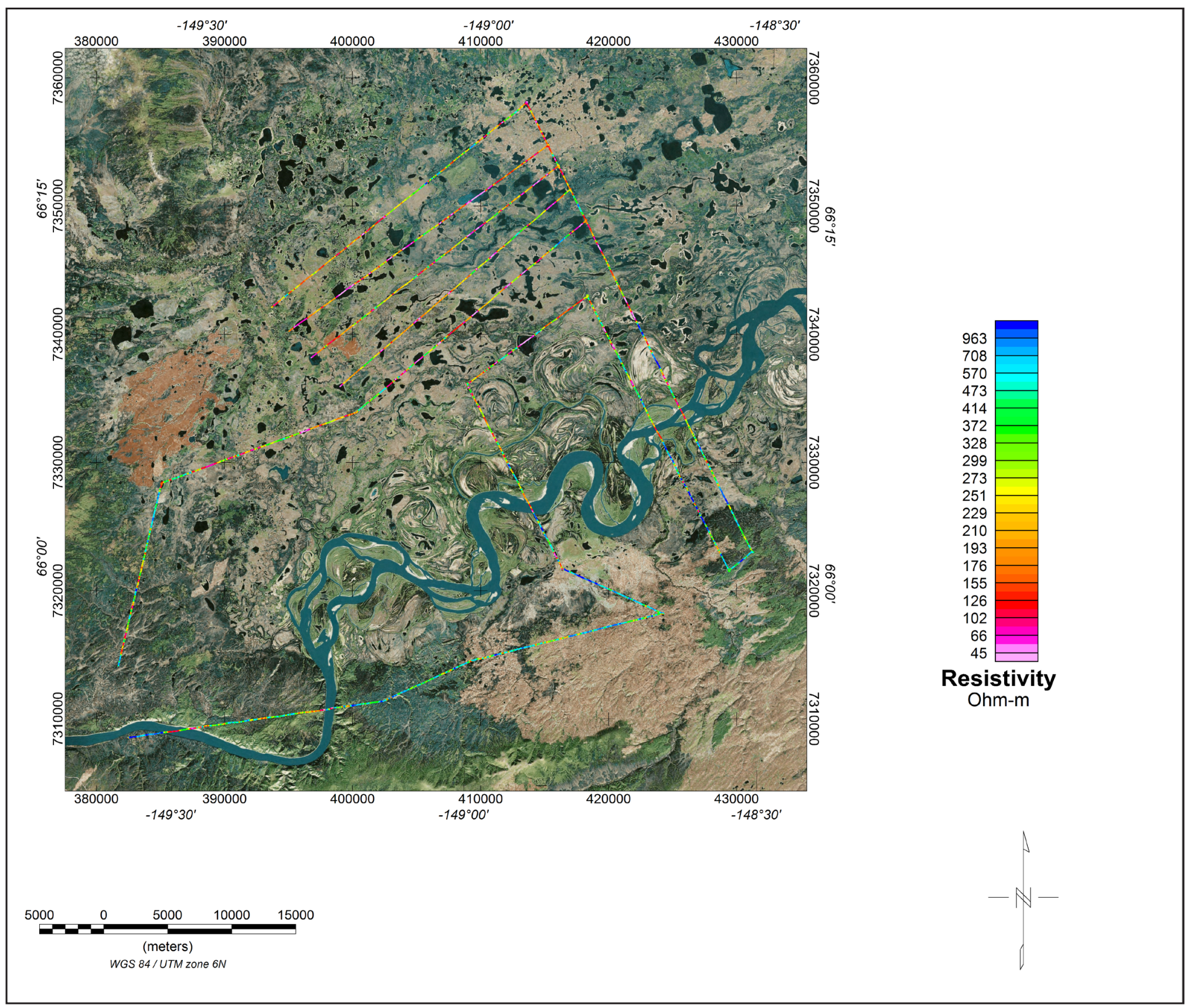

Figure 6. Resistivity model depth-slice grid; at ground surface (first model layer). Resistivity models are created from the recorded electromagnetic data through a process called inversion. Inversion programs create a resistivity model that has a data signature nearly the same as the recorded data. When this occurs the model is said to "fit" the data. This process is non-unique, meaning that many resistivity models could create similar data. The models presented are likely to (but might not) represent the real world distribution of resistivity in the subsurface. The recorded data are influenced by the subsurface on either side of the flight line; therefore, features in the model could be from either side of the flight line. Power lines and other infrastructure can negatively impact the data quality, which could result in missing data and/or cause erroneous models. Resistivity Model "workbench_lci" shown. 


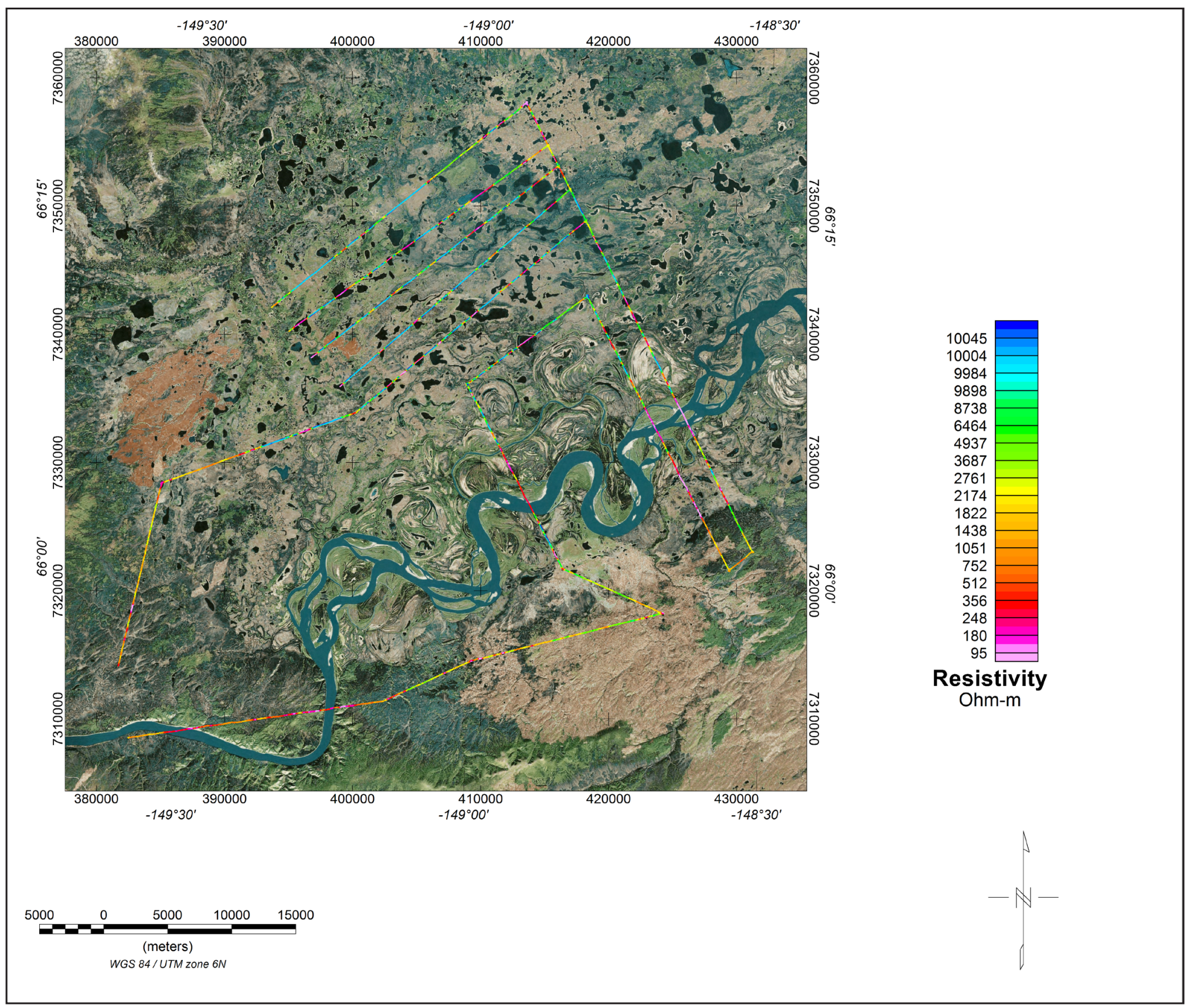

Figure 7. Resistivity model depth-slice grid; 30 meters below ground surface. Resistivity models are created from the recorded electromagnetic data through a process called inversion. Inversion programs create a resistivity model that has a data signature nearly the same as the recorded data. When this occurs the model is said to "fit" the data. This process is non-unique, meaning that many resistivity models could create similar data. The models presented are likely to (but might not) represent the real world distribution of resistivity in the subsurface. The recorded data are influenced by the subsurface on either side of the flight line; therefore, features in the model could be from either side of the flight line. Power lines and other infrastructure can negatively impact the data quality, which could result in missing data and/or cause erroneous models. Resistivity Model "workbench_lci" shown. 
Table 1. Copies of the following maps are included at the end of this booklet. The low-resolution, page-size maps included in this booklet are intended to be used as a search tool and are not the final product. Large-scale, full-resolution versions of each map are available to download on this publication's citation page: $\underline{\text { http://doi.org/10.14509/29683. }}$

\begin{tabular}{|l|l|}
\hline \multicolumn{1}{|c|}{ Map Title } & \multicolumn{1}{c|}{ Description } \\
\hline res400hz_topo_map & $400 \mathrm{~Hz}$ coplanar apparent resistivity grid (electromagnetic data), with topography background \\
\hline res1800hz_topo_map & $1800 \mathrm{~Hz}$ coplanar apparent resistivity grid (electromagnetic data, with topography background \\
\hline res3300hz_topo_map & $3300 \mathrm{~Hz}$ coaxial apparent resistivity grid (electromagnetic data), with topography background \\
\hline res8200hz_topo_map & $8200 \mathrm{~Hz}$ coplanar apparent resistivity grid (electromagnetic data), with topography background \\
\hline res40khz_topo_map & $40000 \mathrm{~Hz}$ coplanar apparent resistivity grid (electromagnetic data), with topography background \\
\hline res140khz_topo_map & $140000 \mathrm{~Hz}$ coplanar apparent resistivity grid (electromagnetic data), with topography background \\
\hline residualmag_topo_map & residual magnetic intensity grid (magnetic data), with topography background \\
\hline
\end{tabular}




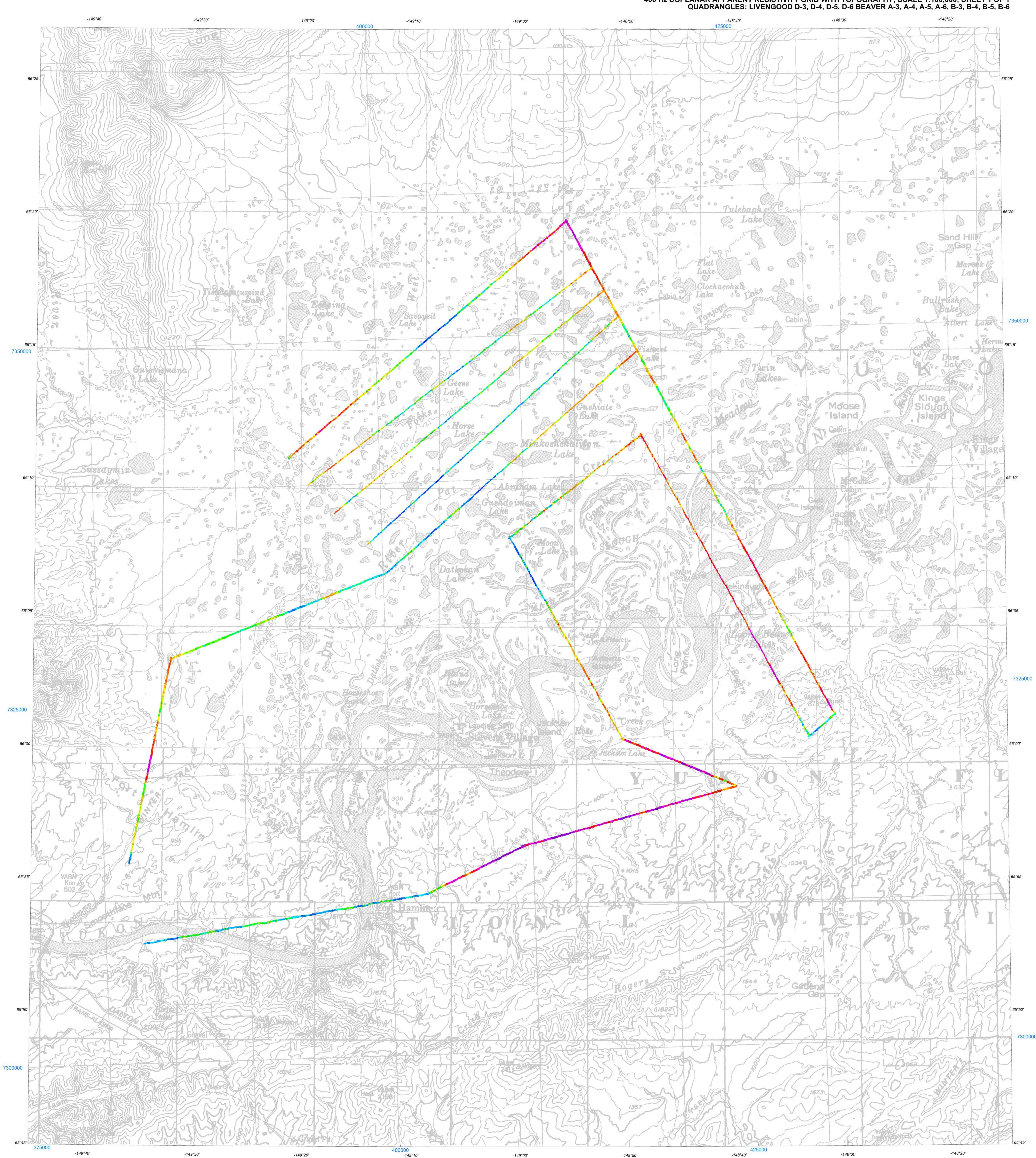

SURVEY LOCATION

AIRBORNE ELECTROMAGNETIC AND MAGNETIC SURVEY WESTERN YUKON FLATS, INTERIOR ALASKA http://doi.org/10.14509/29683

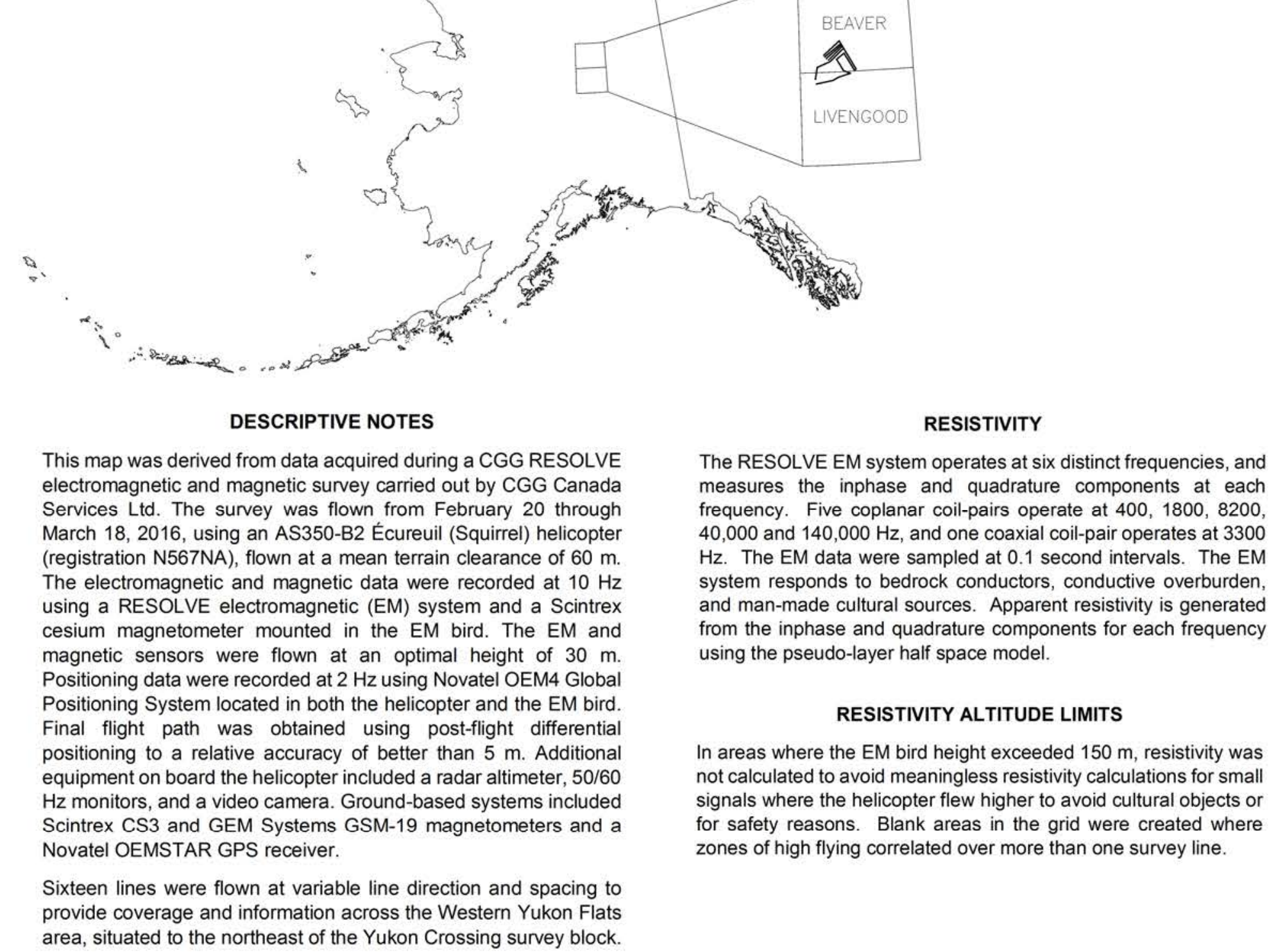

APPARENT RESISTIVITY $400 \mathrm{~Hz}$ COPLANAR WITH TOPOGRAPHY

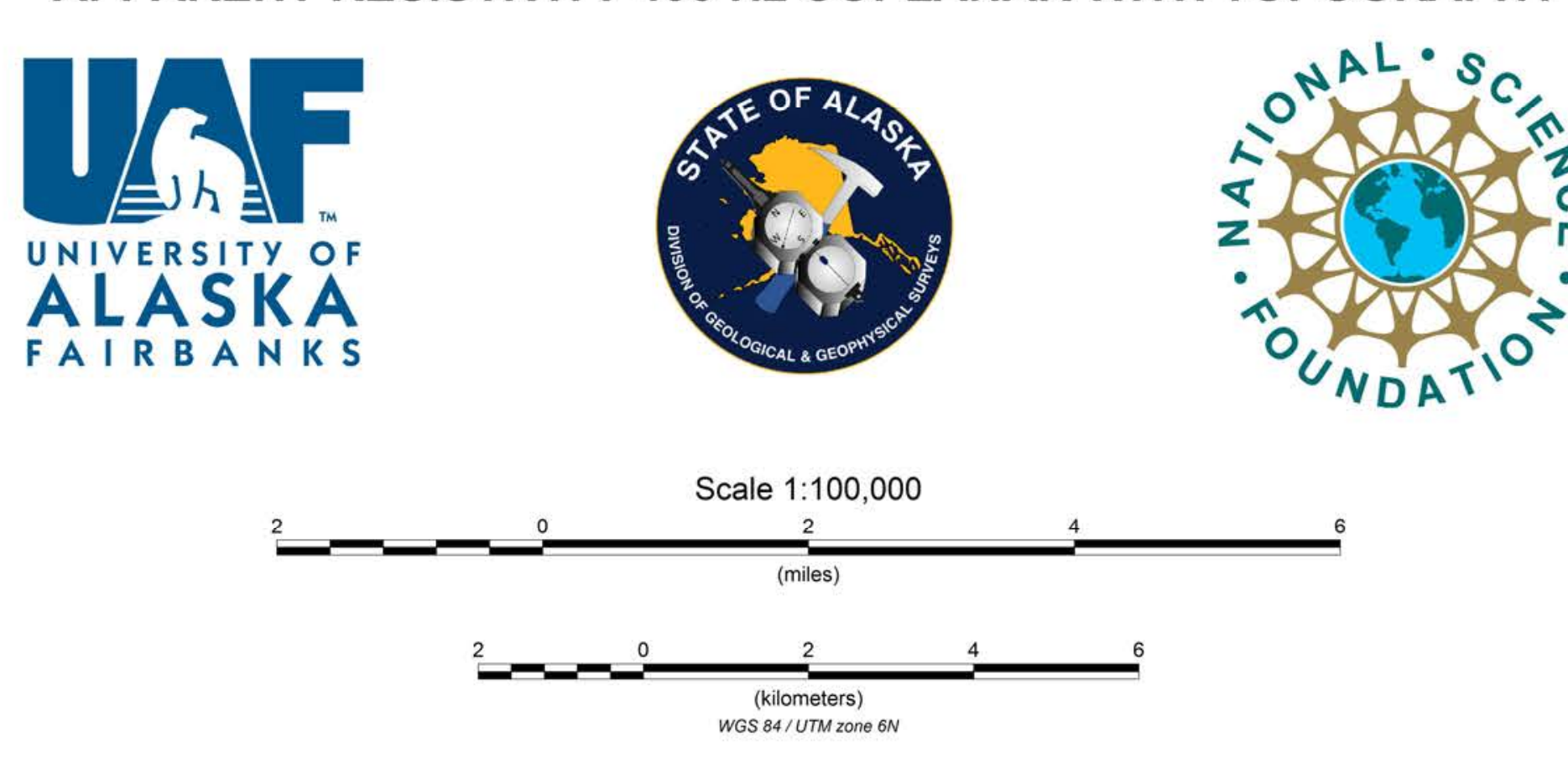

Emond, A.M., Minsley, B.J., Daanen, R.P., Graham, G.C., and CGG Canada Services Ltd.

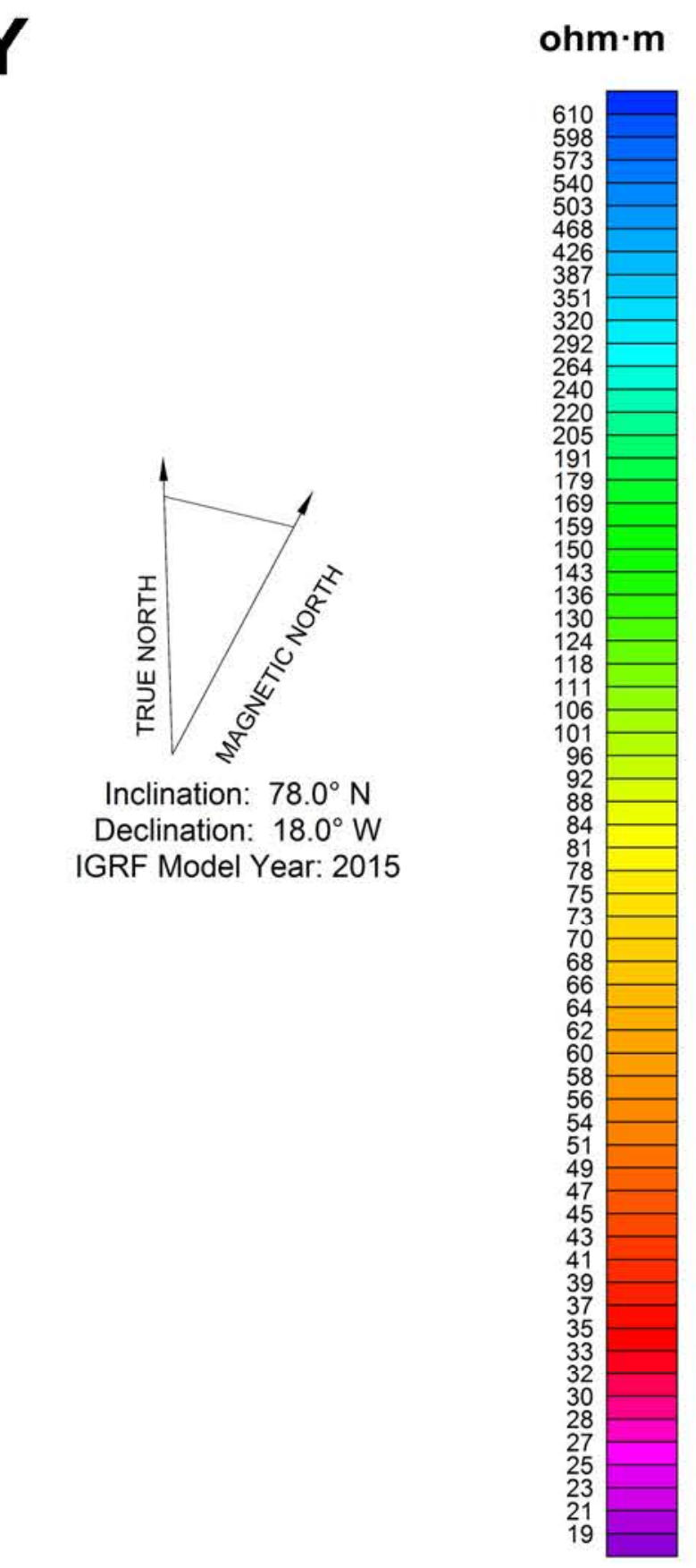

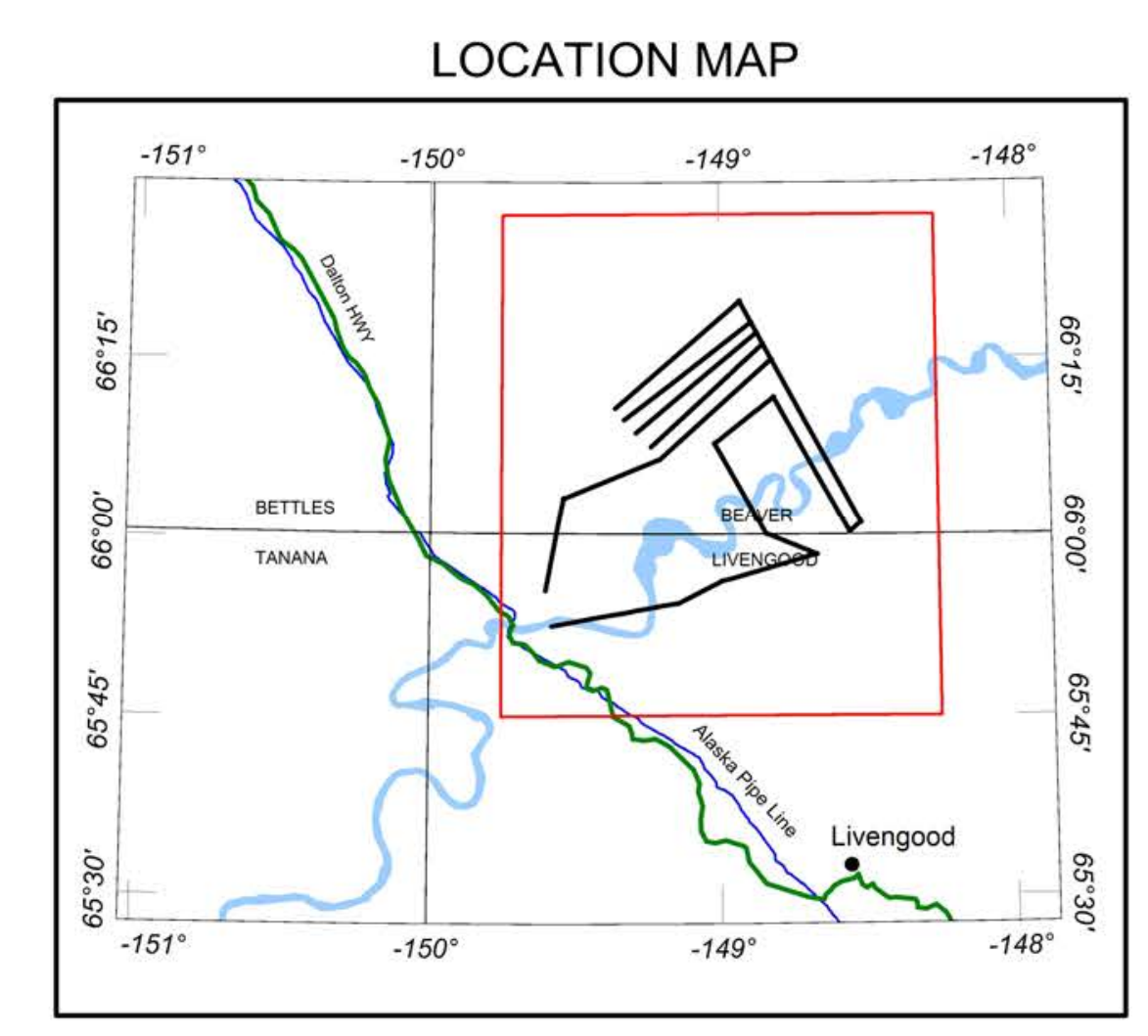

SURVEY YHISTORY

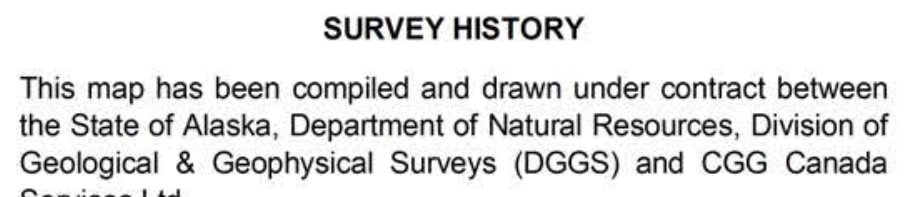

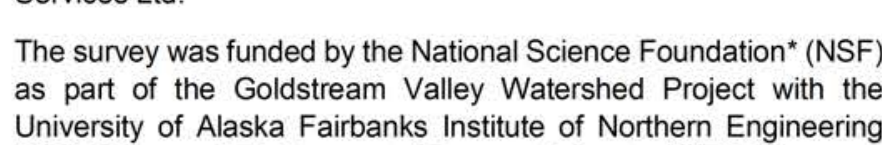

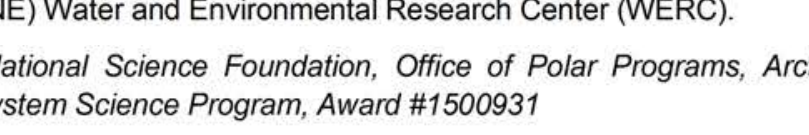

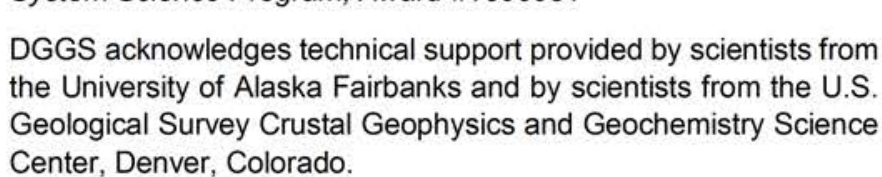

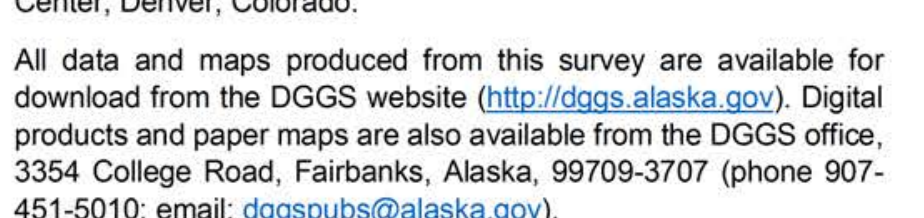




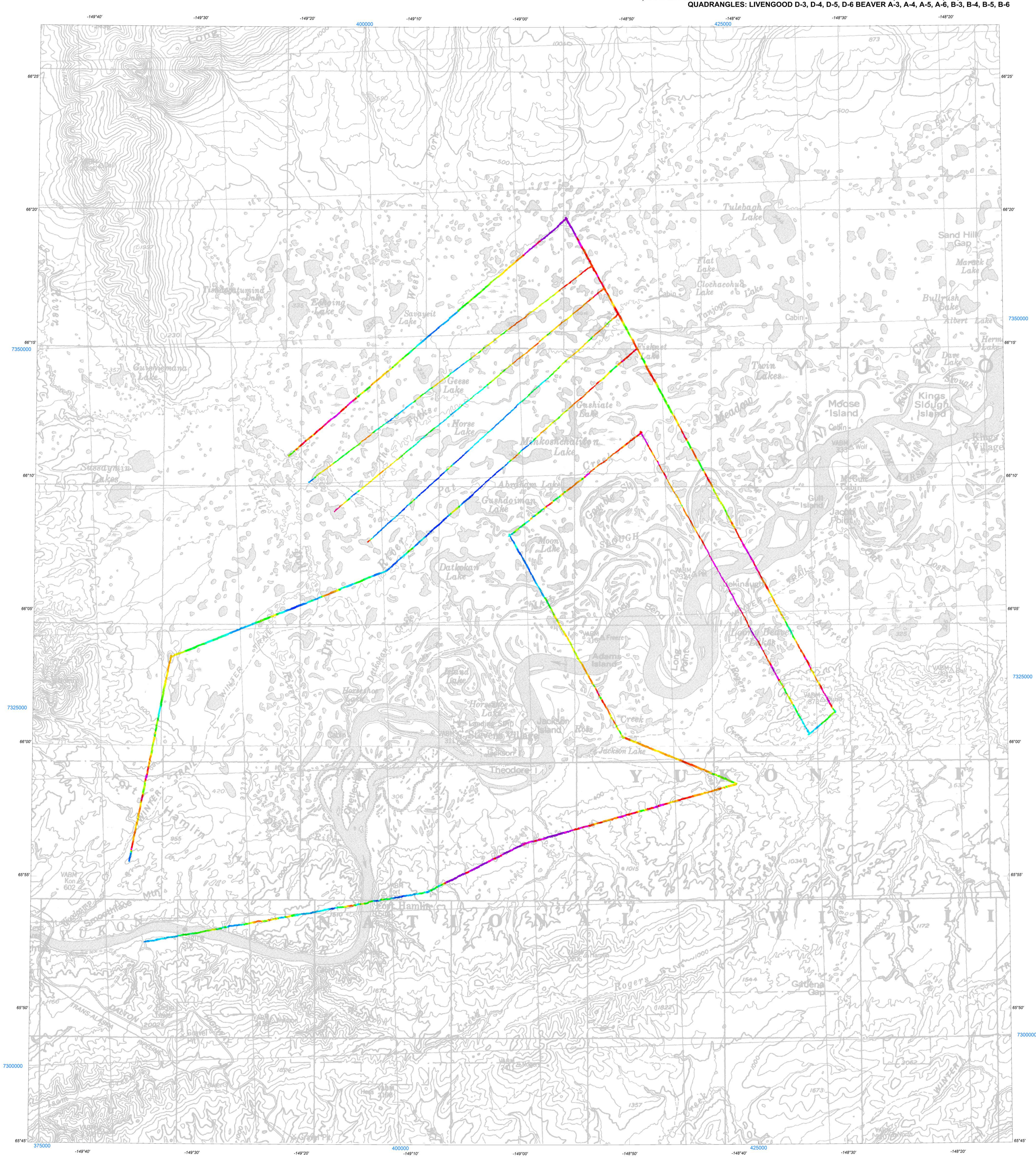

SURVEY LOCATION

AIRBORNE ELECTROMAGNETIC AND MAGNETIC SURVEY WESTERN YUKON FLATS, INTERIOR ALASKA

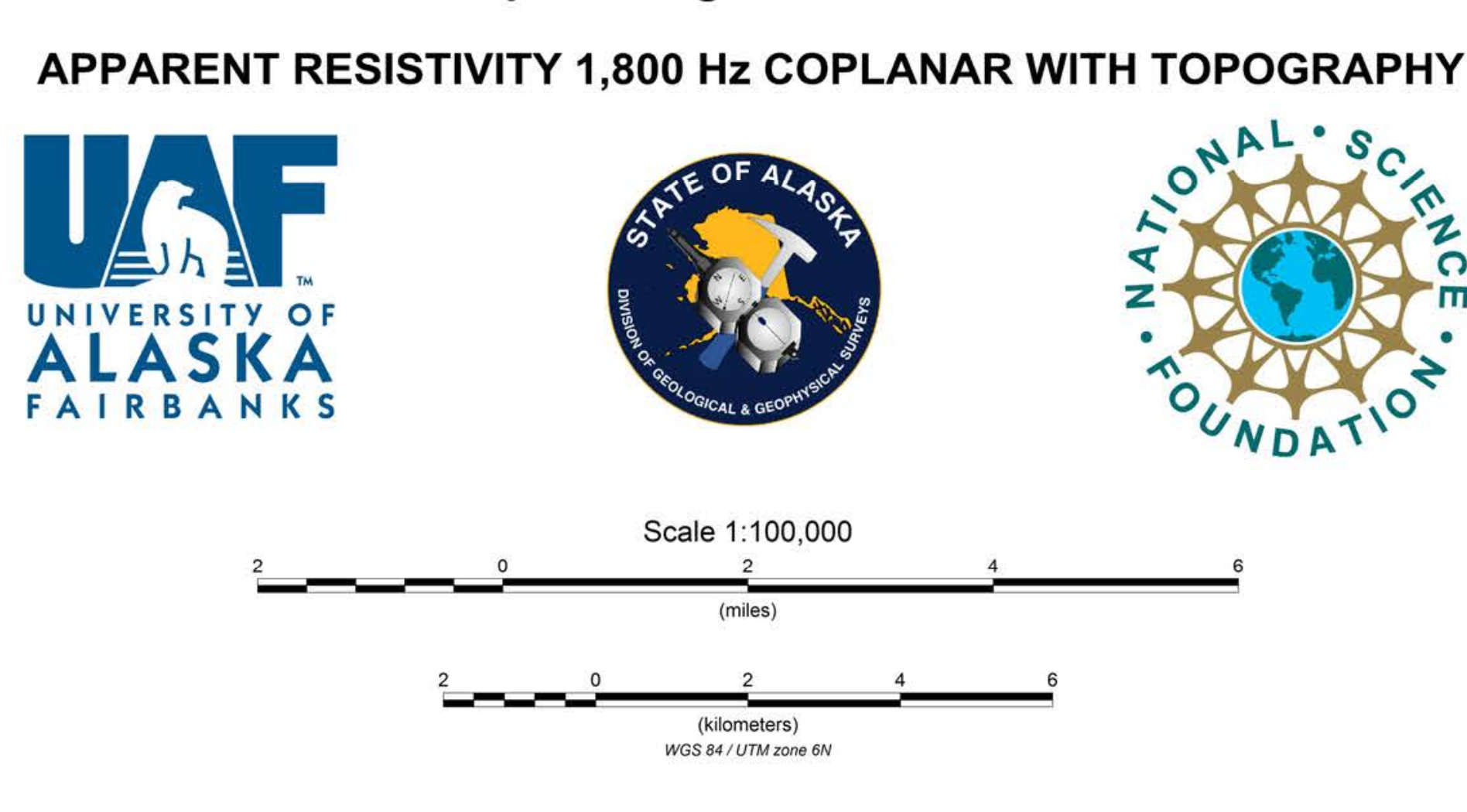

Emond, A.M., Minsley, B.J,, Daanen, R.P., Graham, G.C., and CGG Canada Services Ltd.

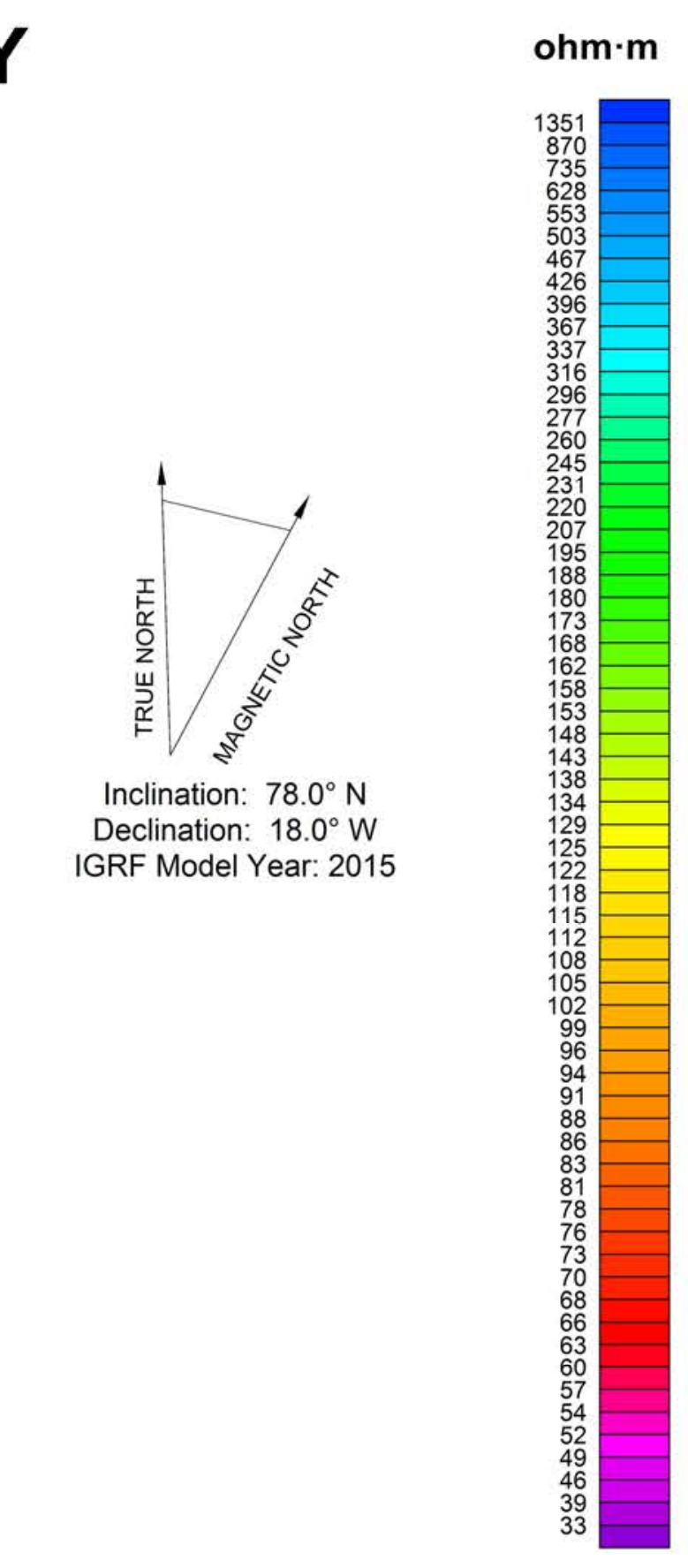

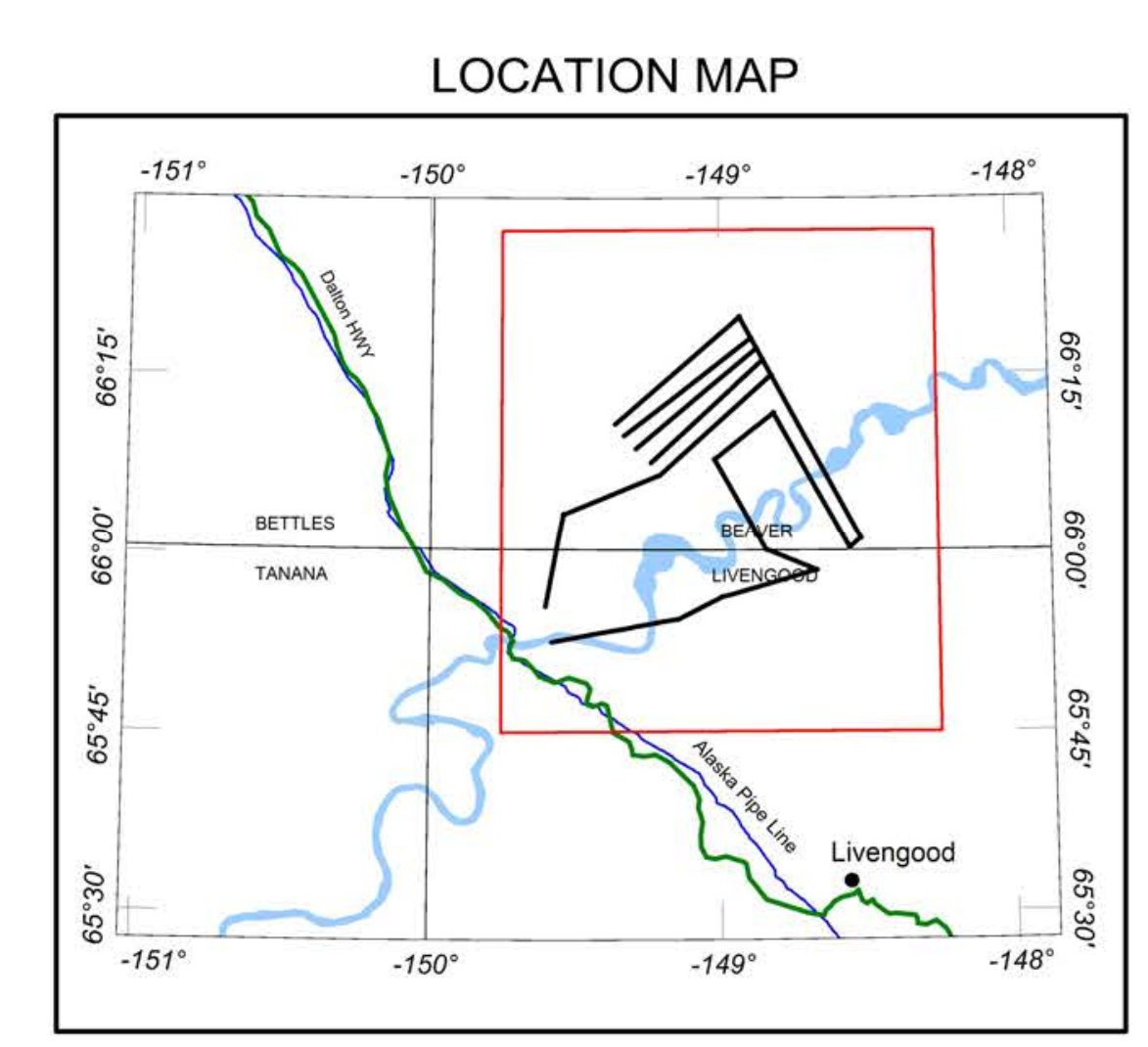

SURVEYHISTORY

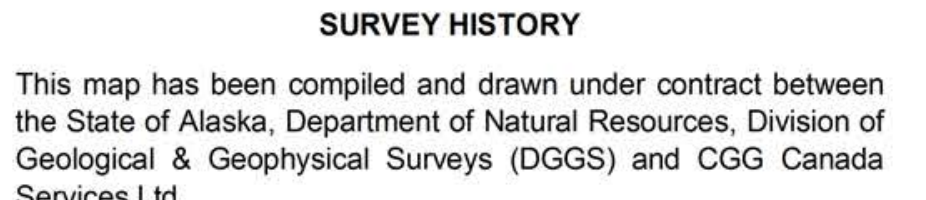

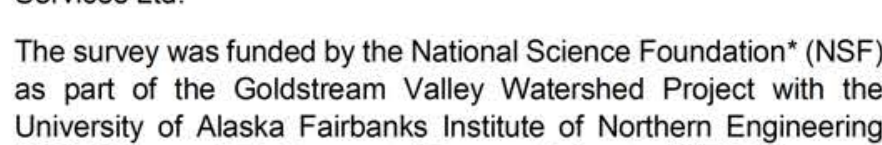

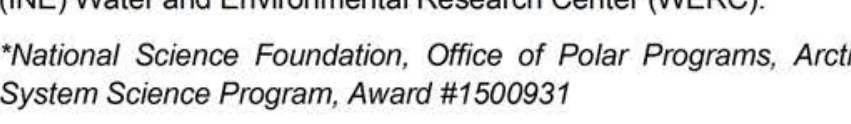

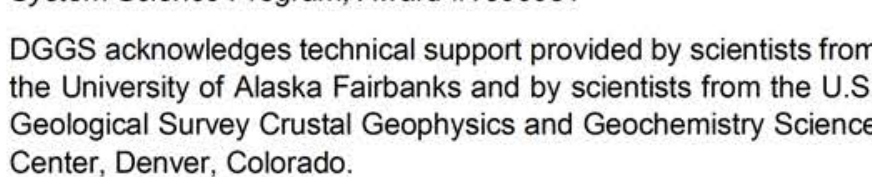

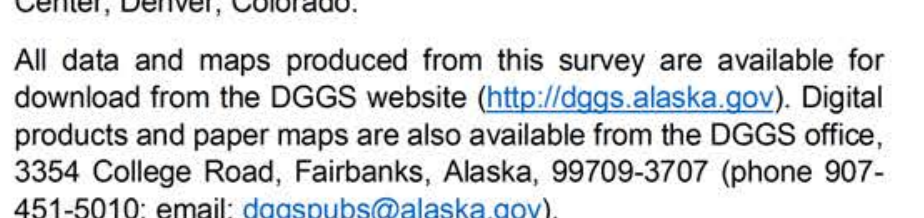




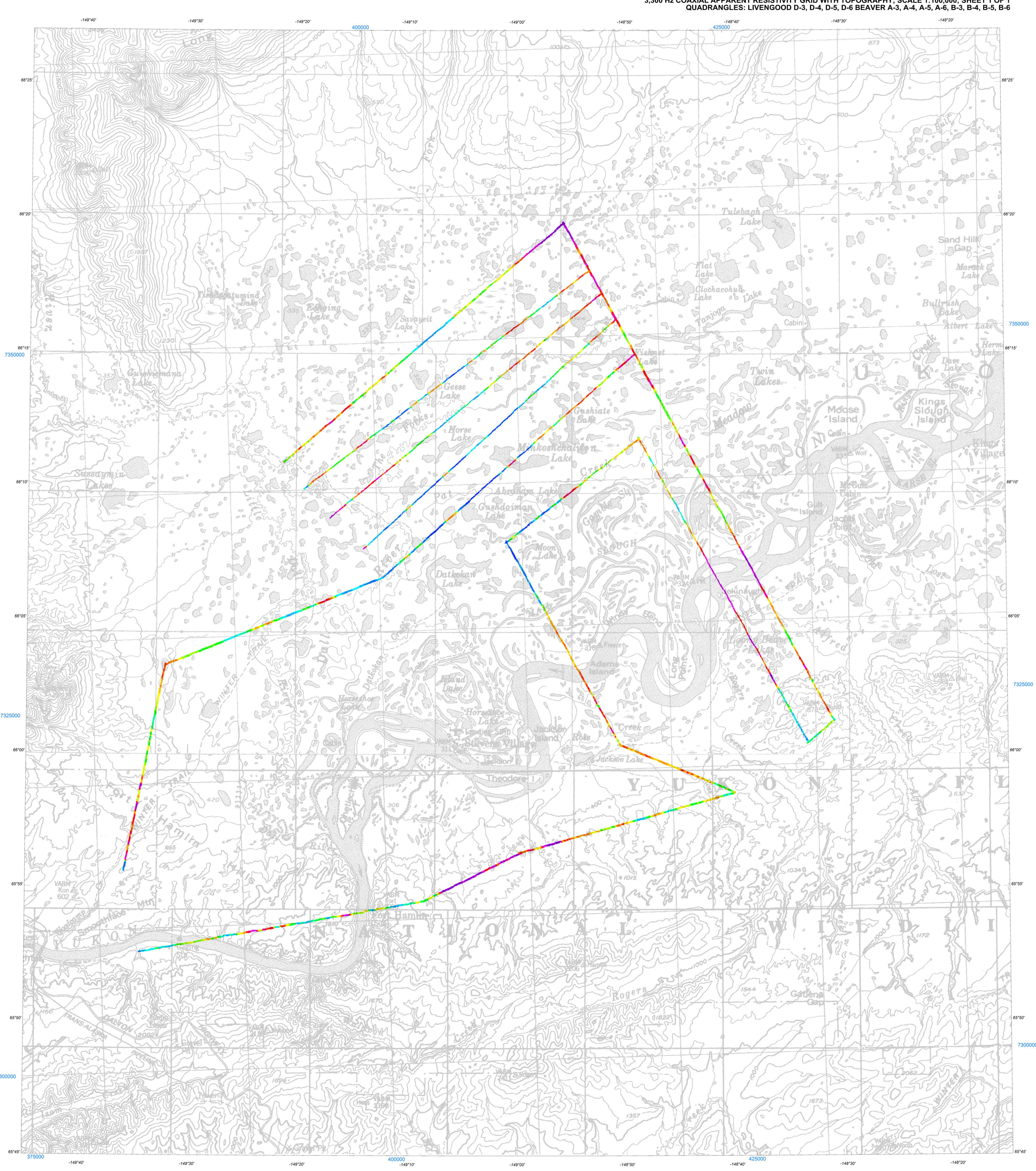

SURVEY LOCATION

AIRBORNE ELECTROMAGNETIC AND MAGNETIC SURVEY WESTERN YUKON FLATS, INTERIOR ALASKA http://doi.org/10.14509/29683

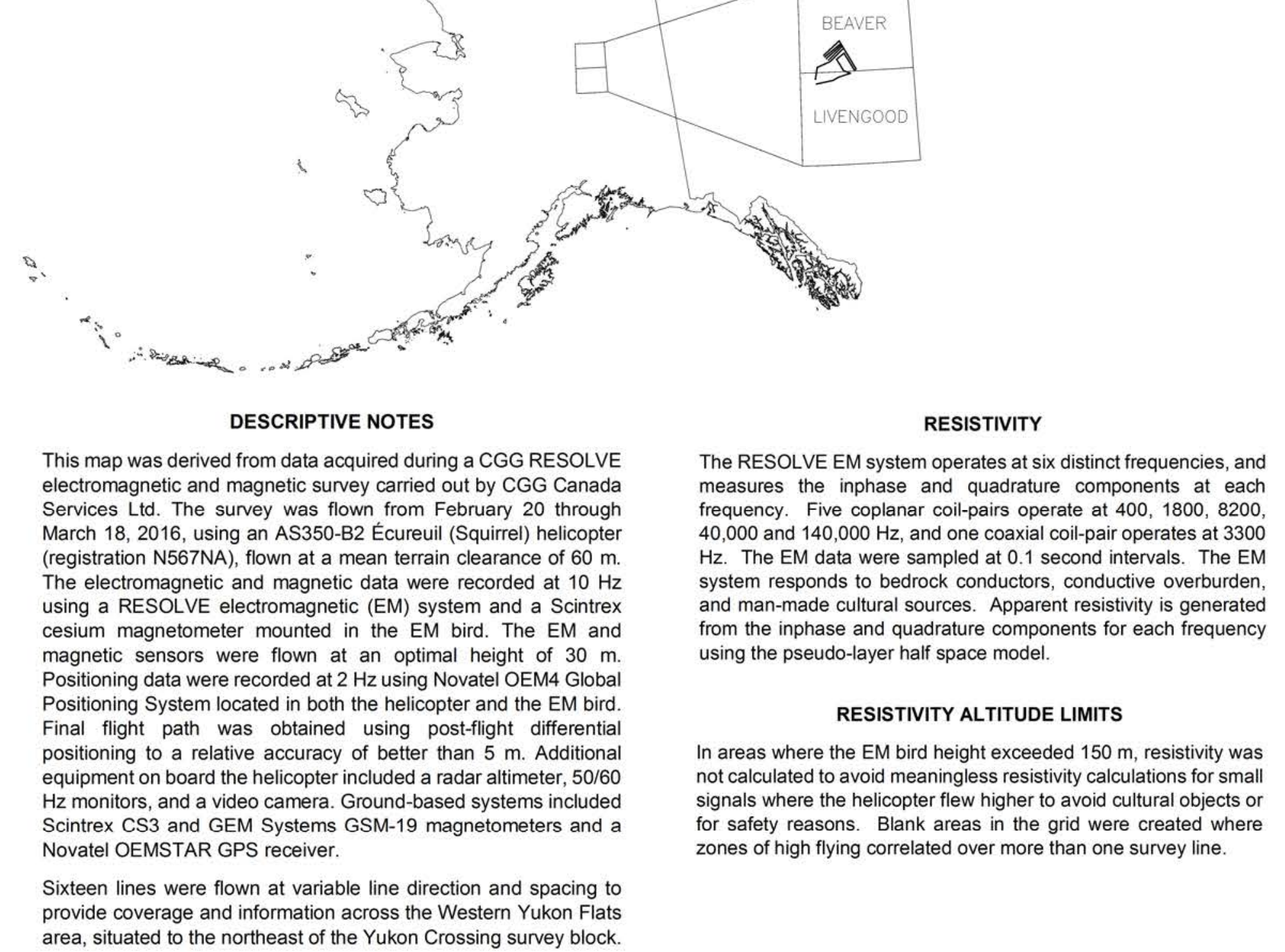

APPARENT RESISTIVITY 3,300 Hz COAXIAL WITH TOPOGRAPHY

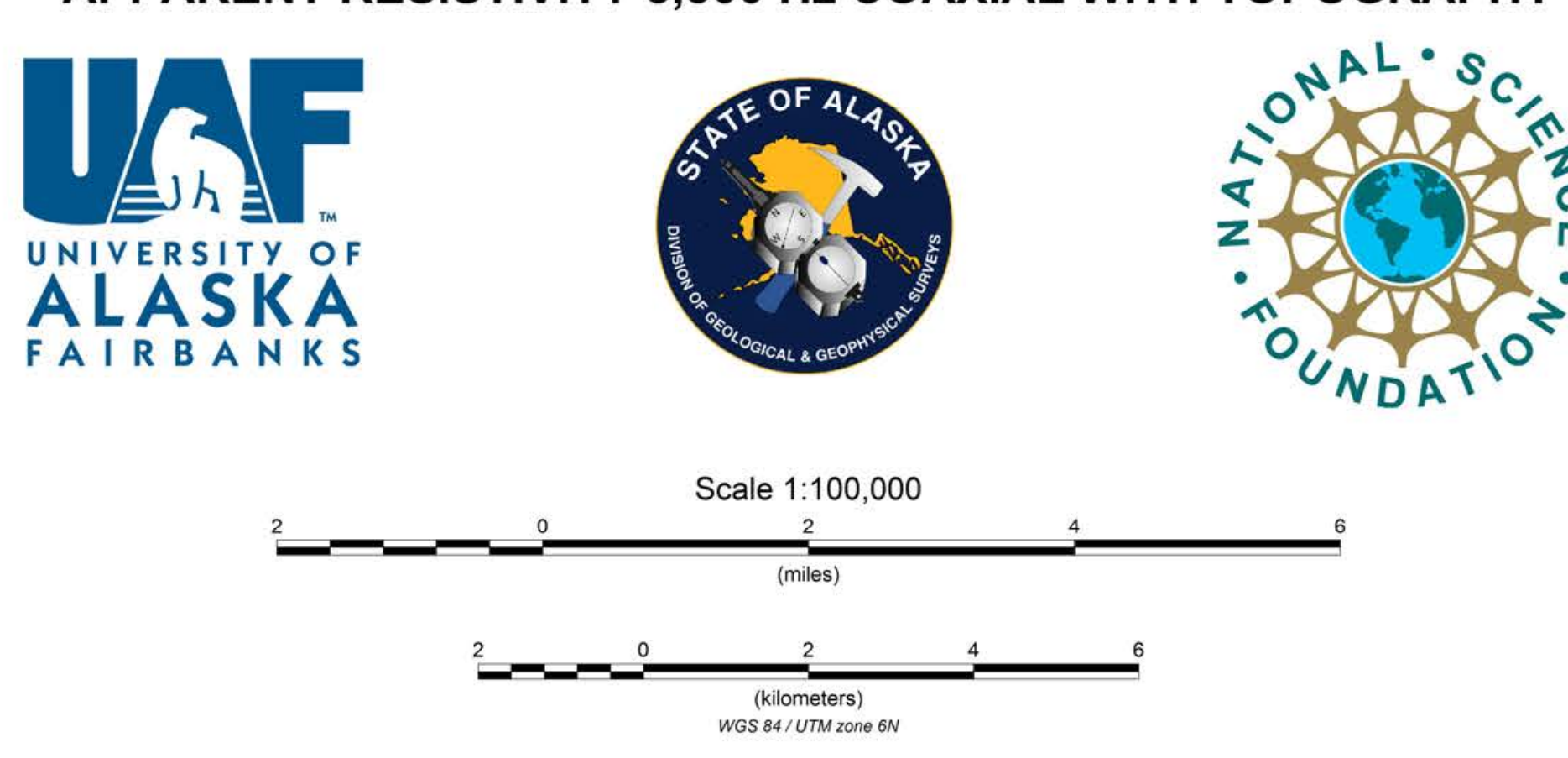

Emond, A.M., Minsley, B.J., Daanen, R.P., Graham, G.C., and CGG Canada Services Ltd.

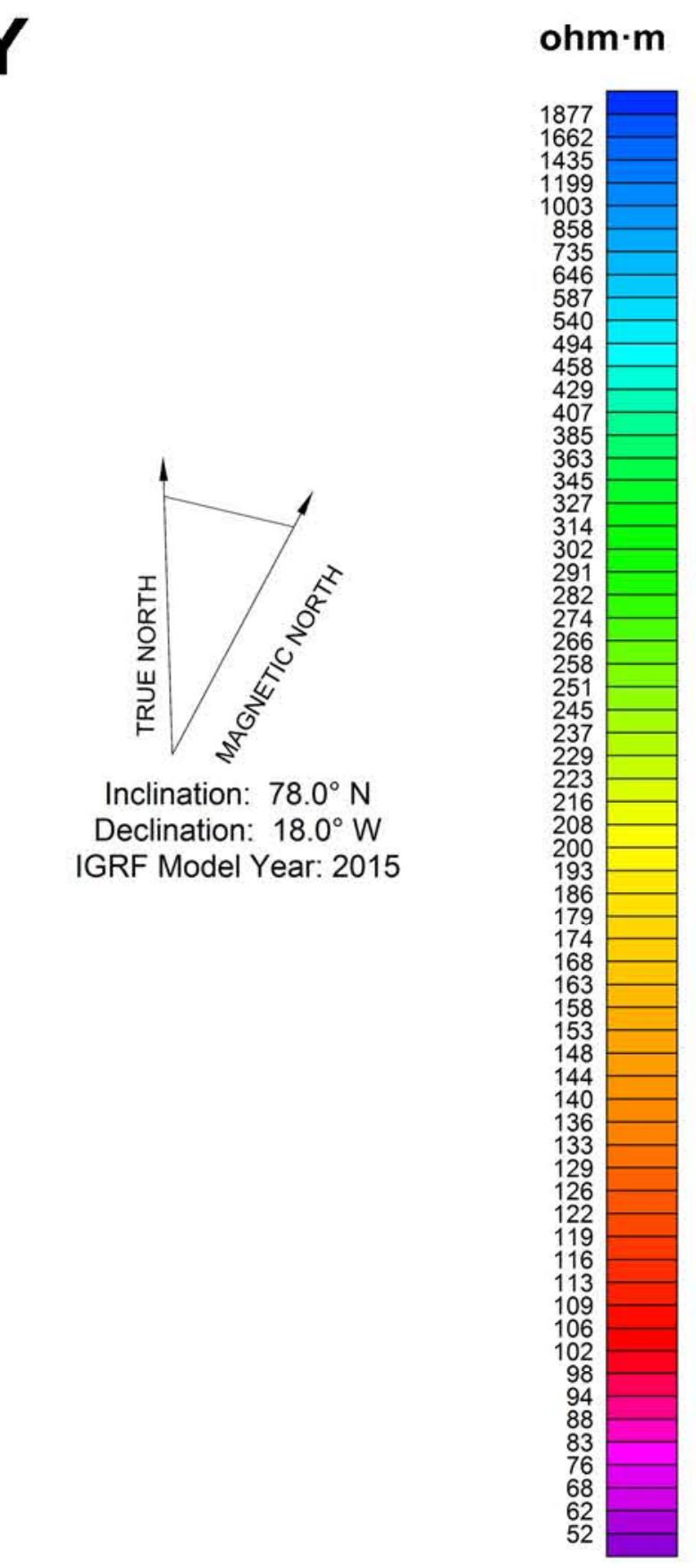

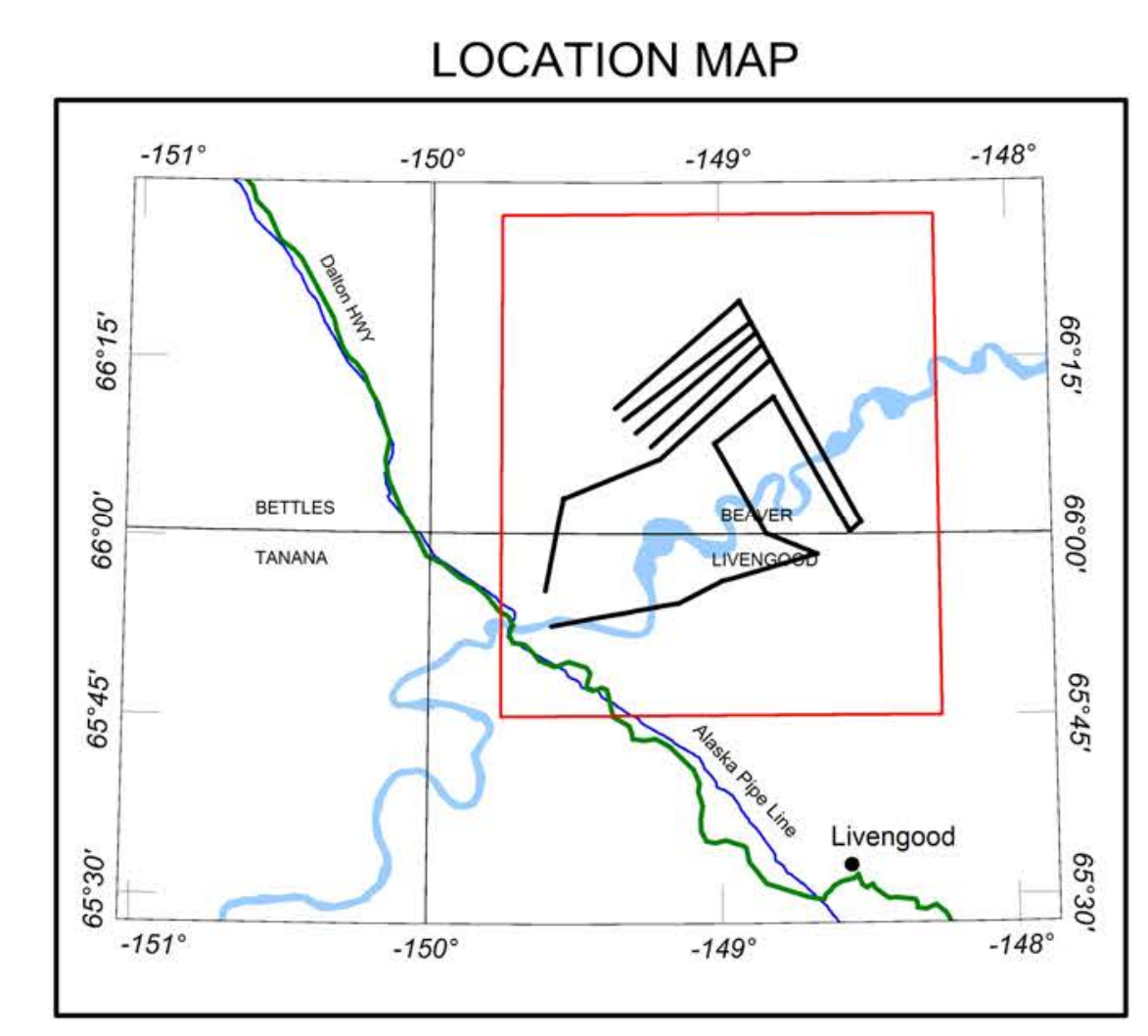

SURVEY YHISTORY

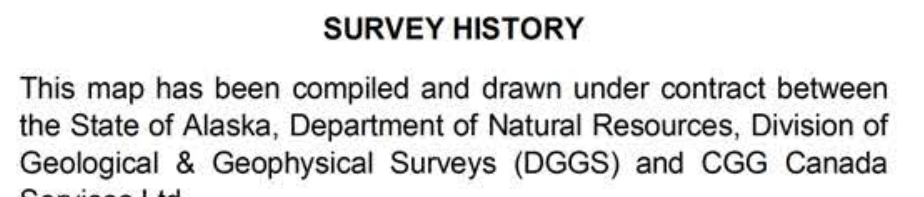

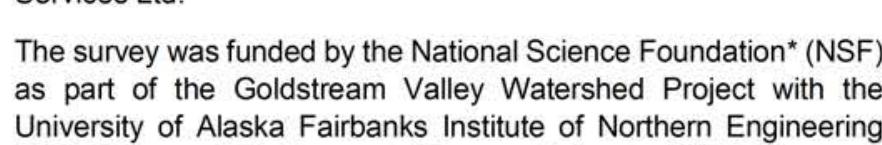

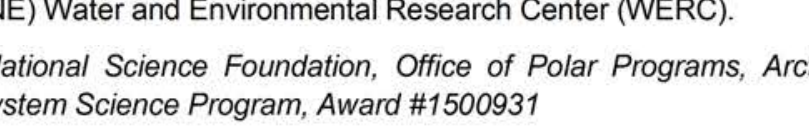

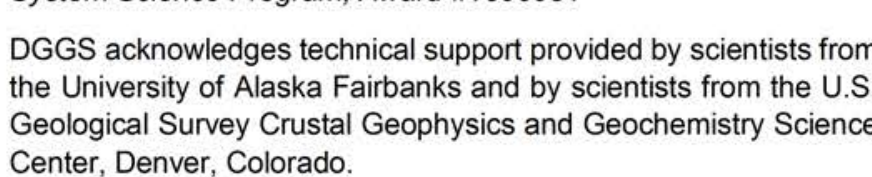

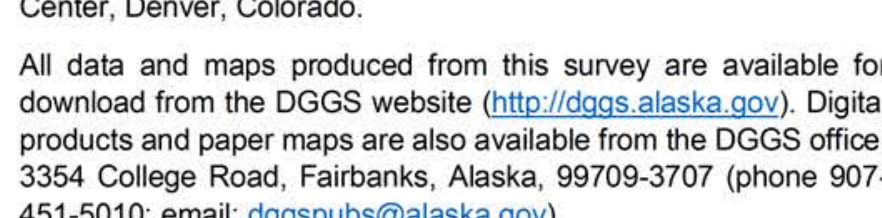




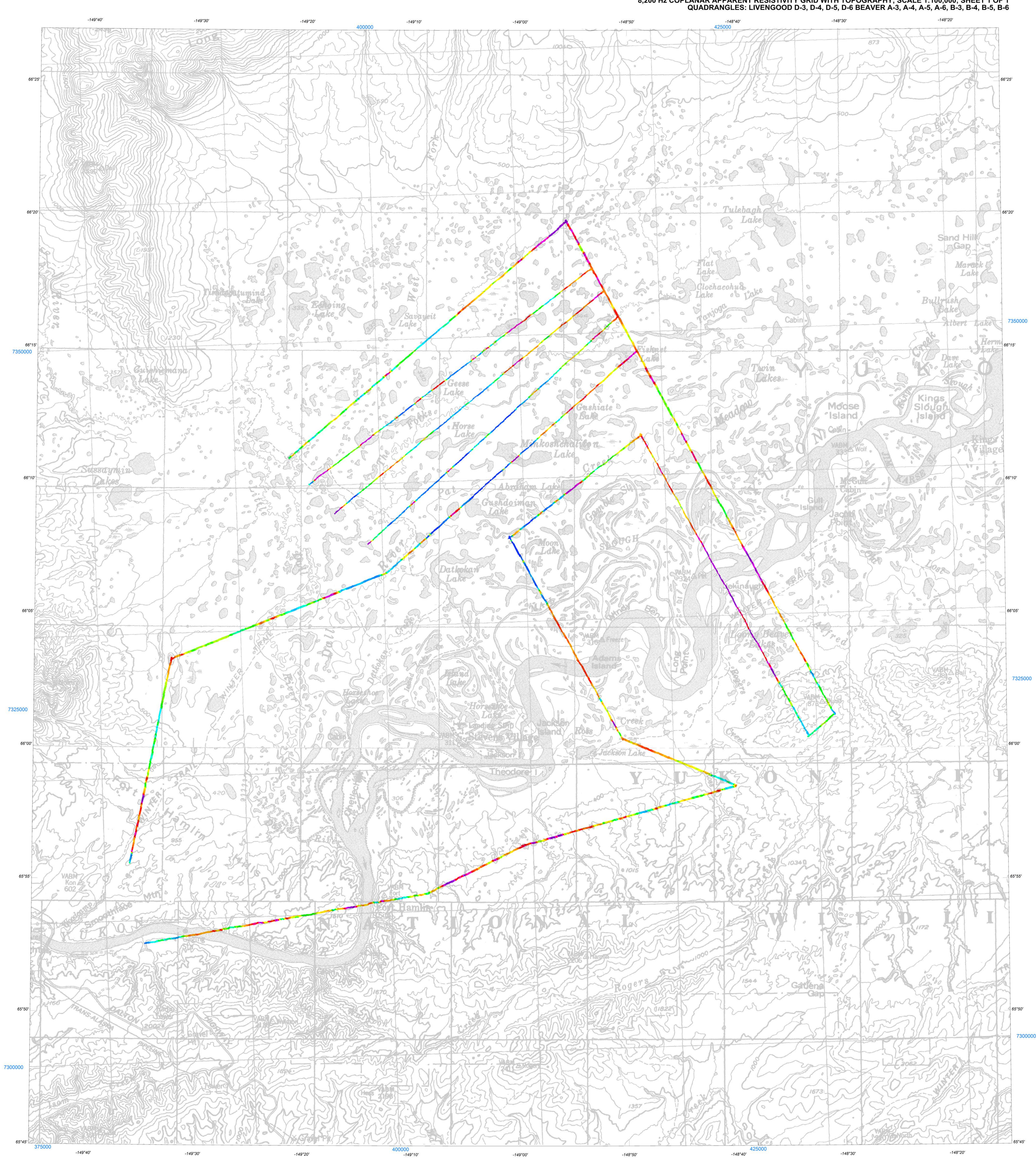

SURVEY LOCATION

AIRBORNE ELECTROMAGNETIC AND MAGNETIC SURVEY WESTERN YUKON FLATS, INTERIOR ALASKA

http://doi.org/10.14509/29683

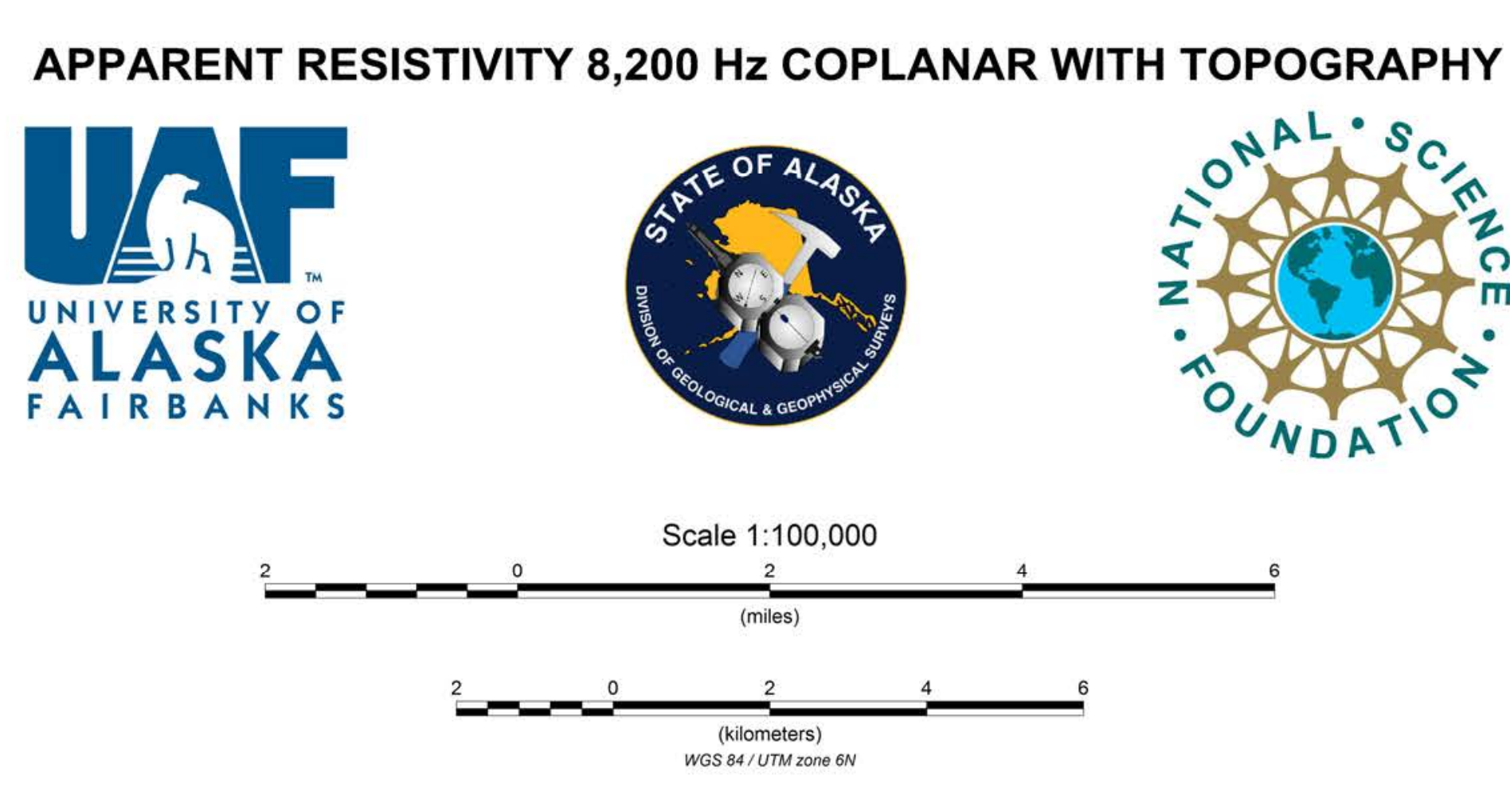

Emond, A.M., Minsley, B.J., Daanen, R.P., Graham, G.C., and CGG Canada Services Ltd.

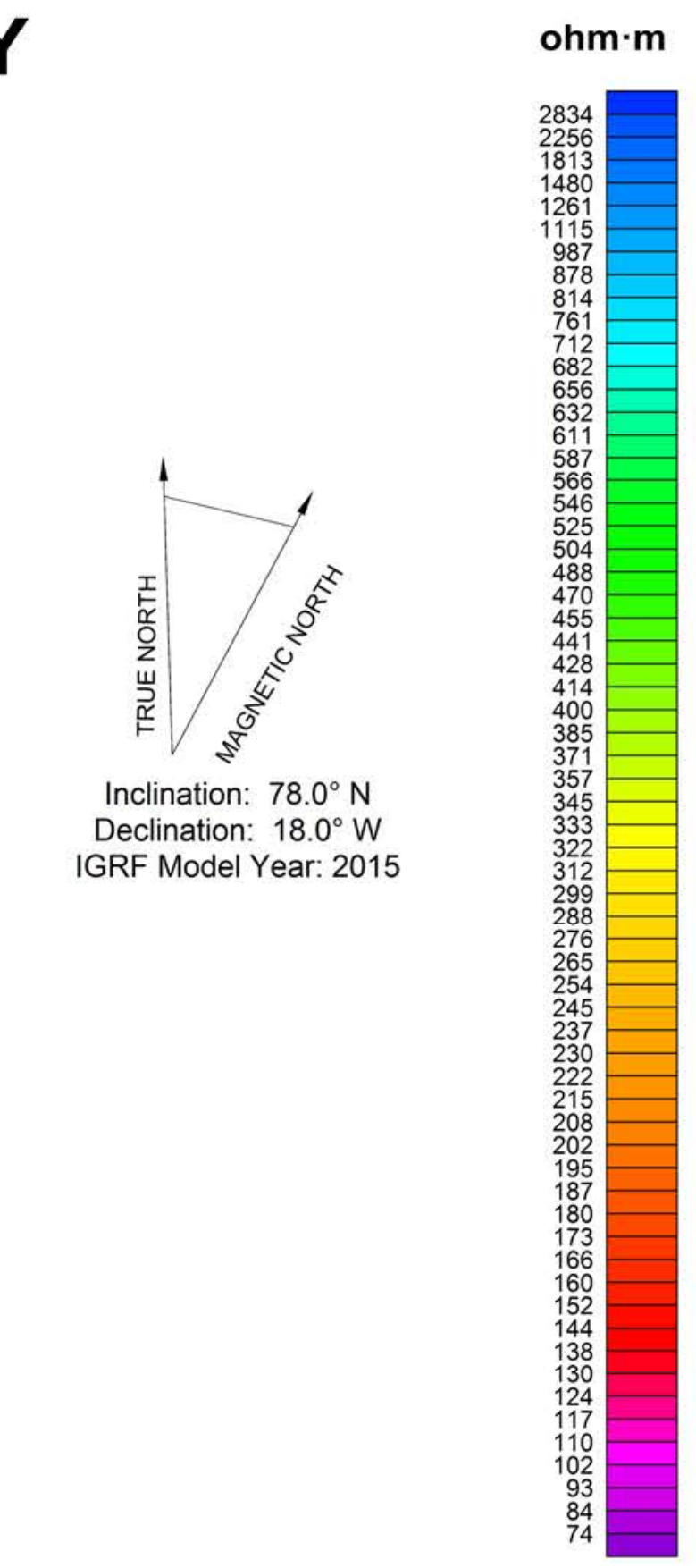

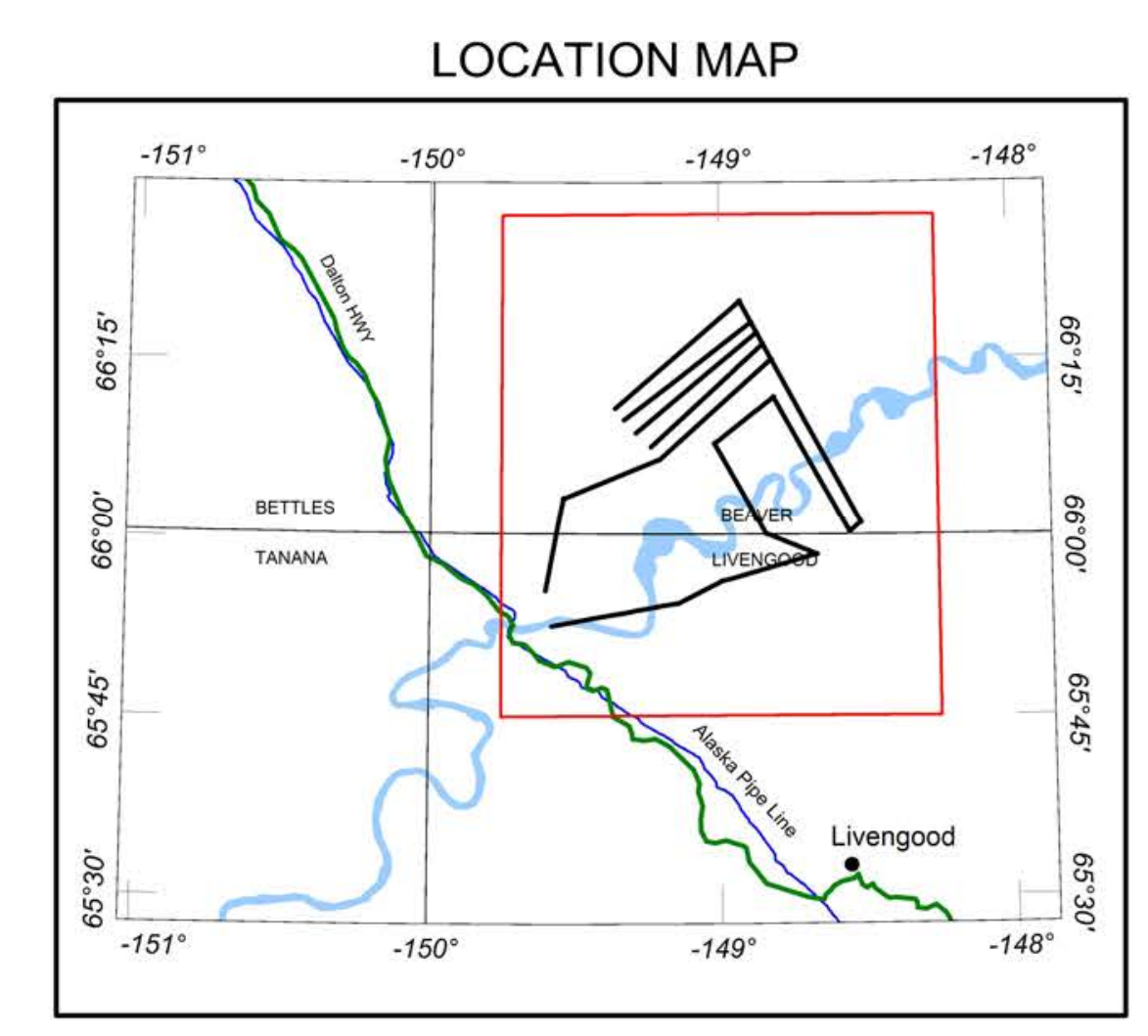

SURVEYHISTORY

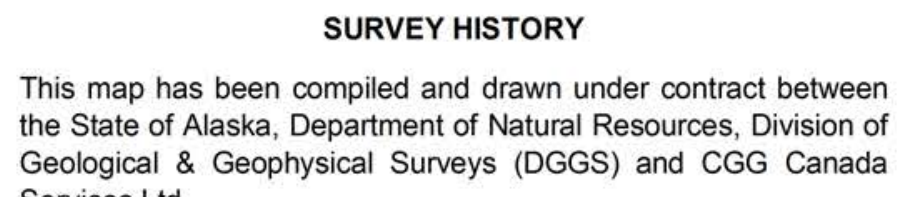

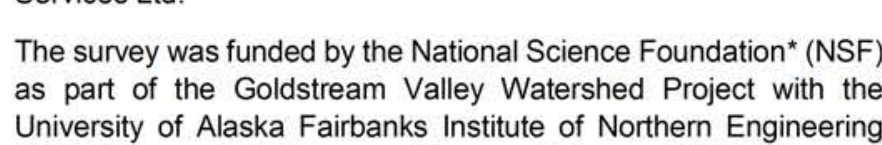

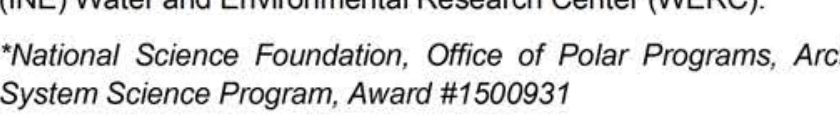

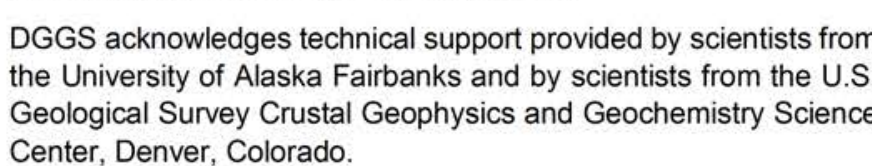

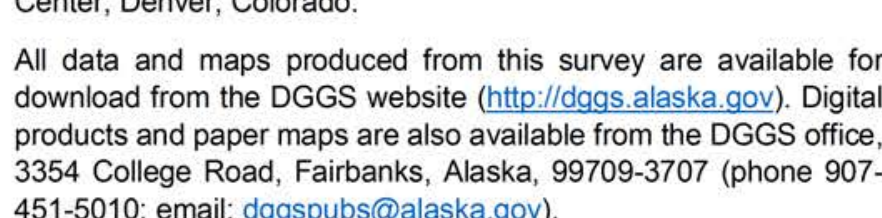




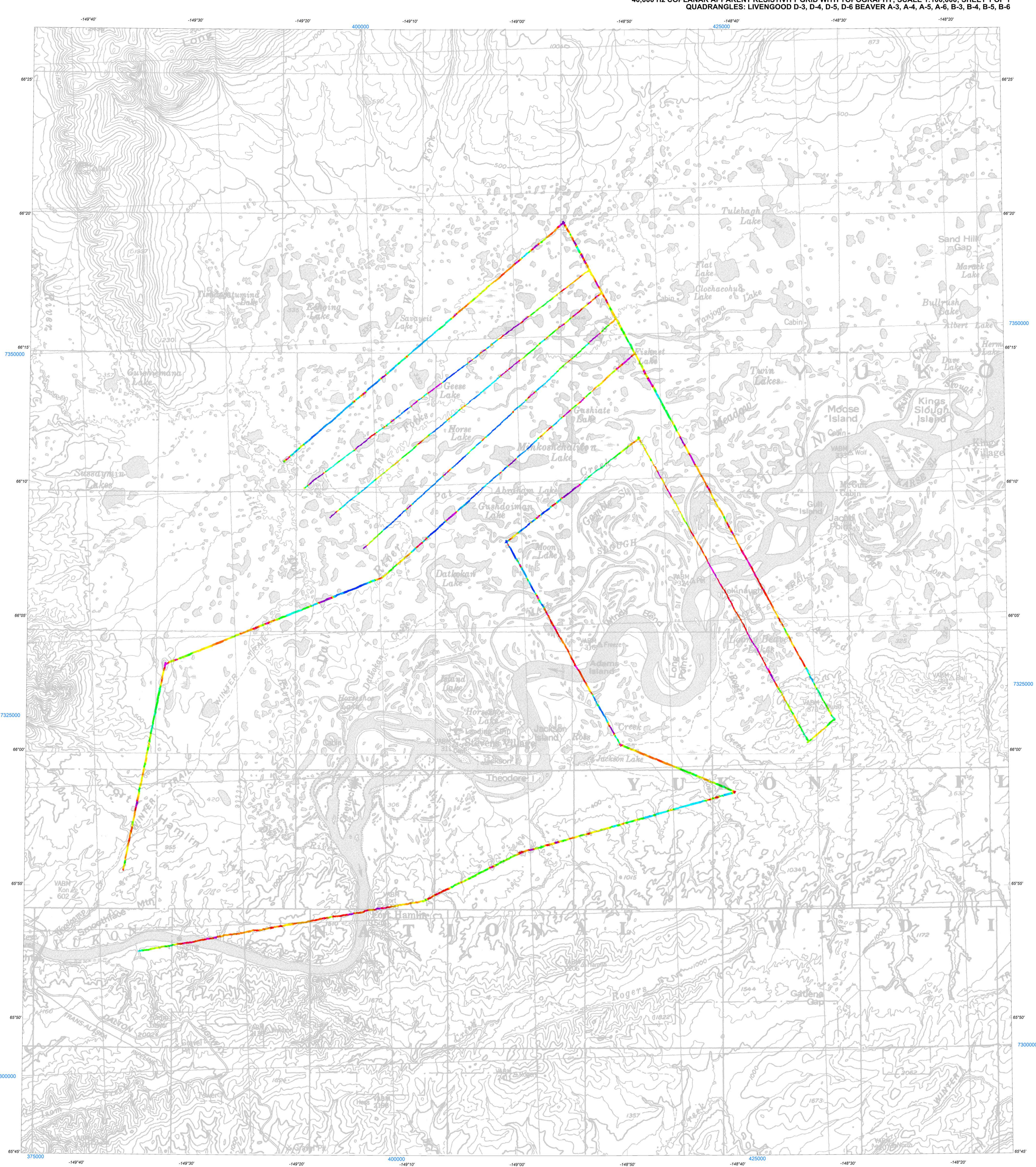

SURVEY LOCATION

AIRBORNE ELECTROMAGNETIC AND MAGNETIC SURVEY WESTERN YUKON FLATS, INTERIOR ALASKA http://doi.org/10.14509/29683

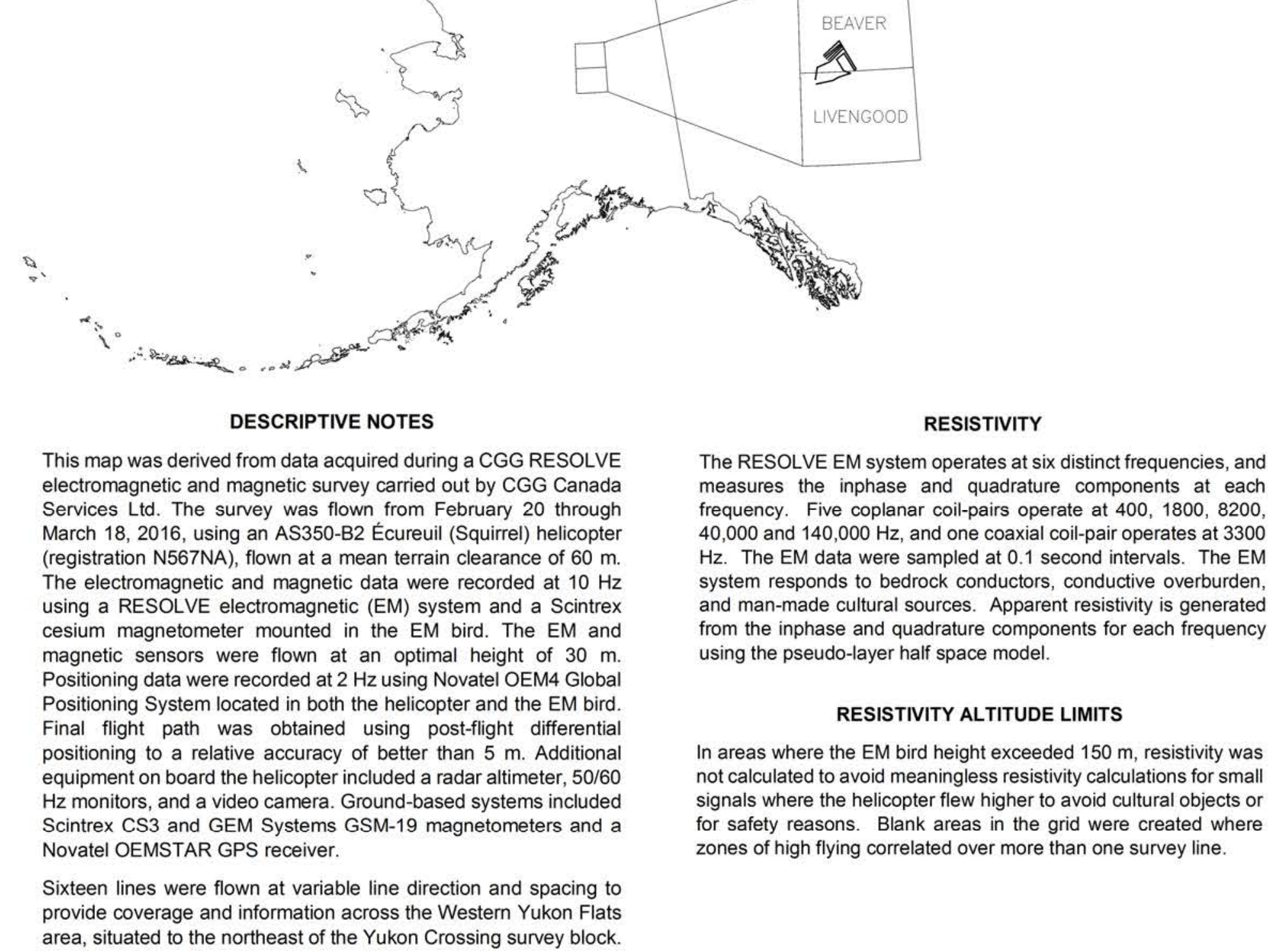

APPARENT RESISTIVITY 40,000 Hz COPLANAR WITH TOPOGRAPHY

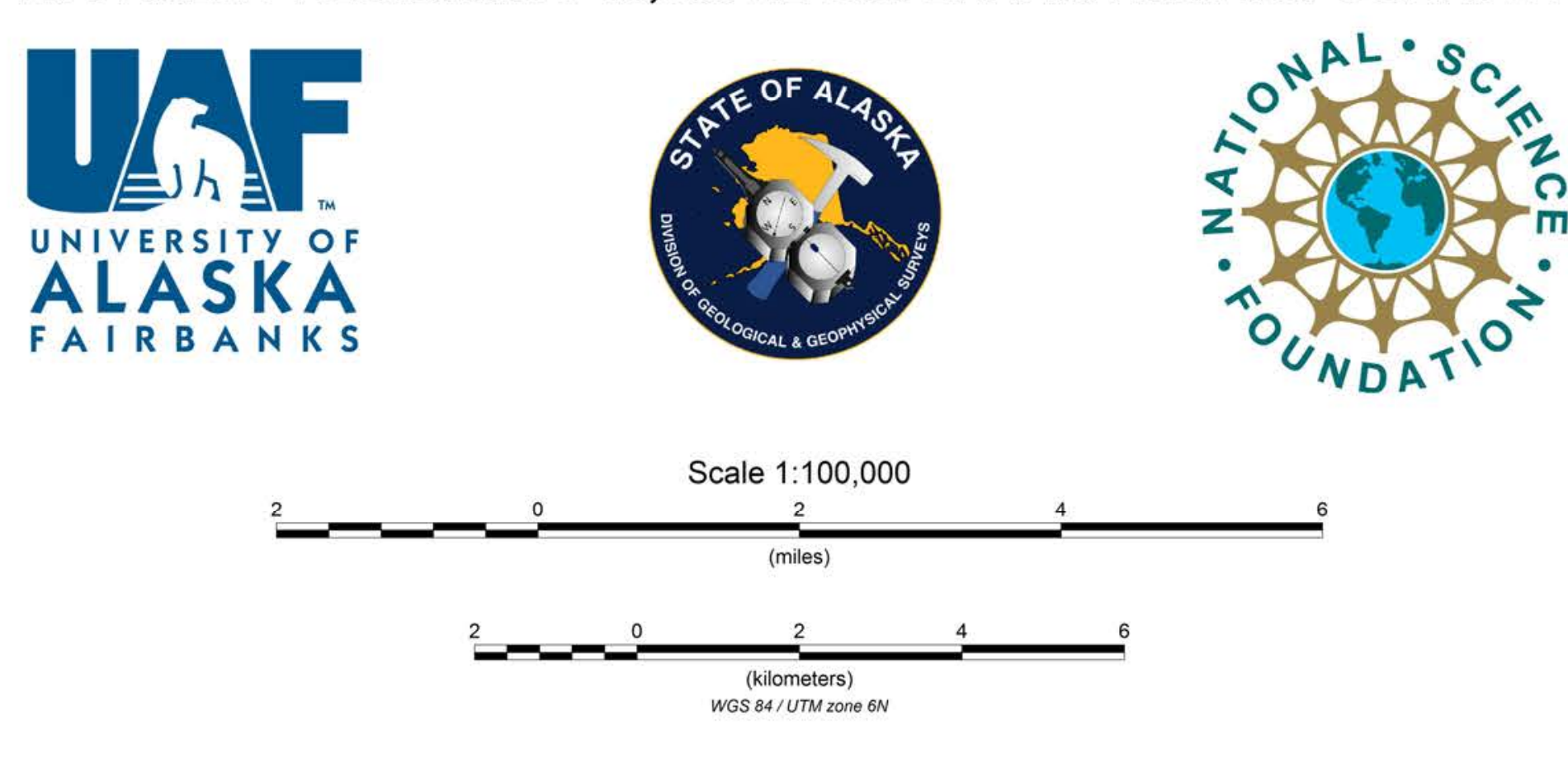

Emond, A.M., Minsley, B.J., Daanen, R.P., Graham, G.C., and CGG Canada Services Ltd.

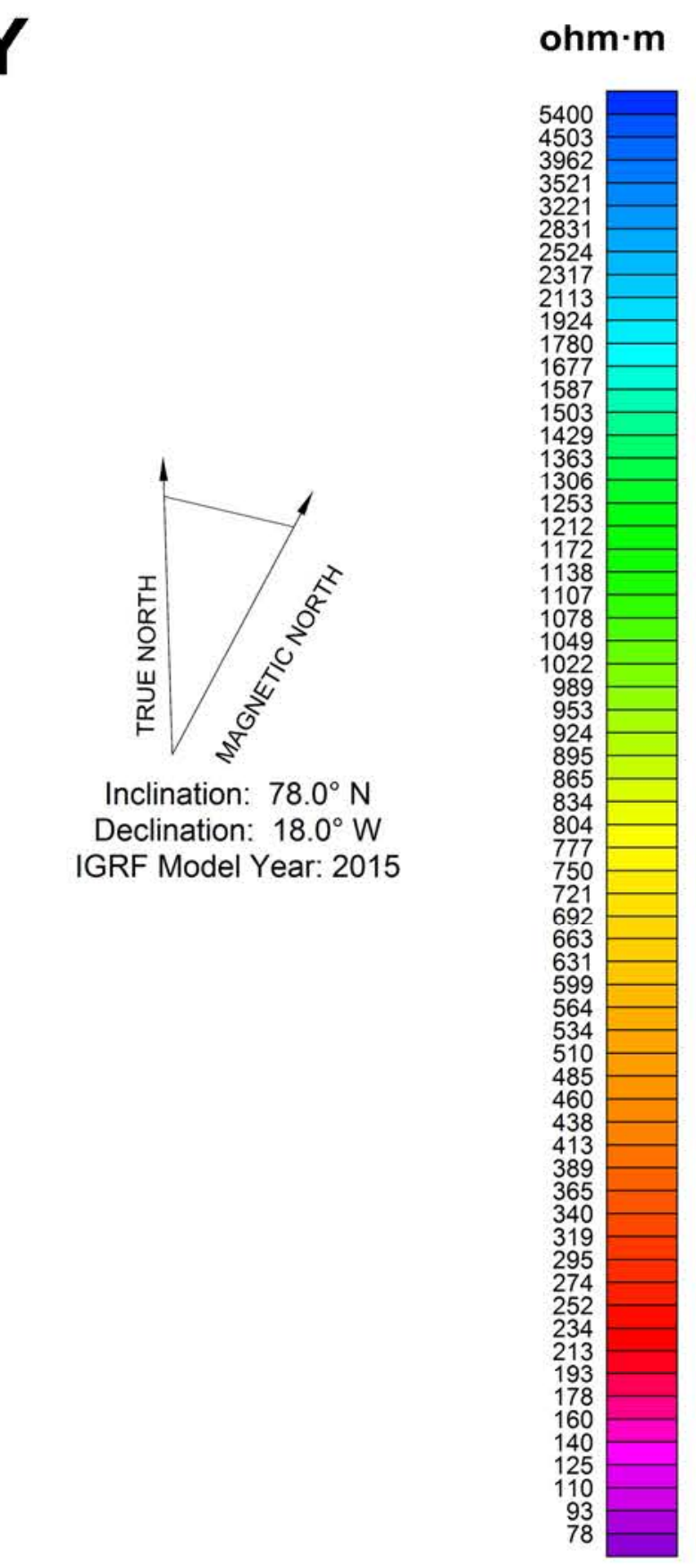

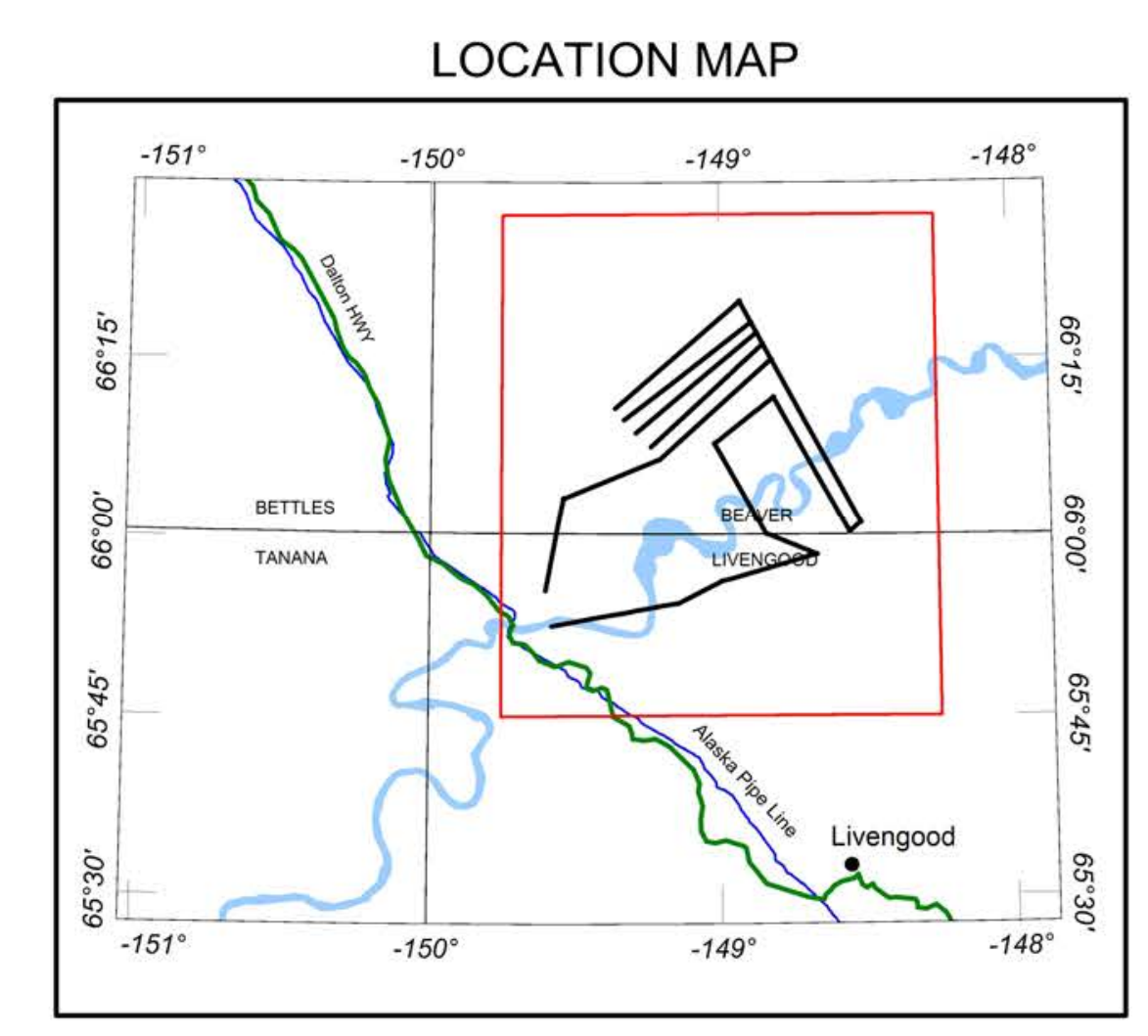

SURVEYHISTORY

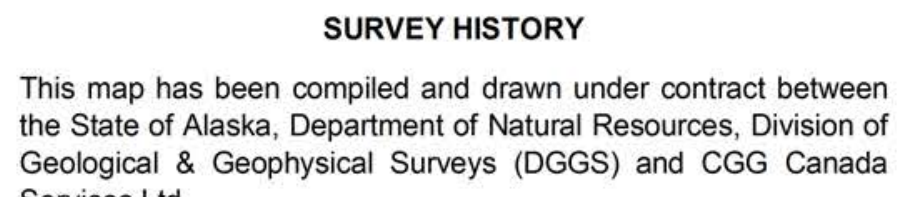

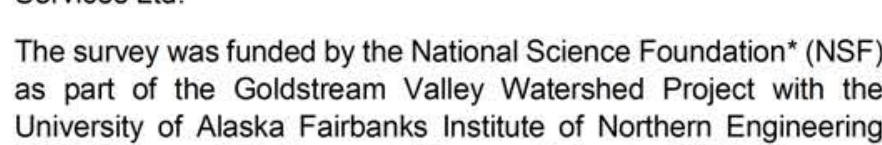

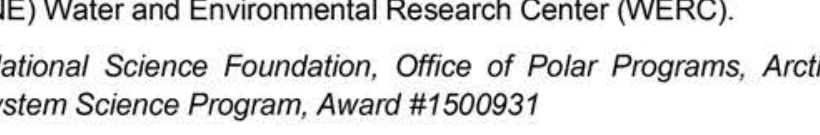

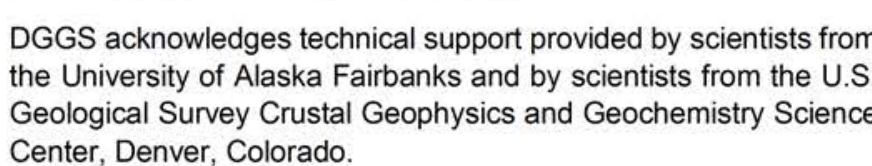

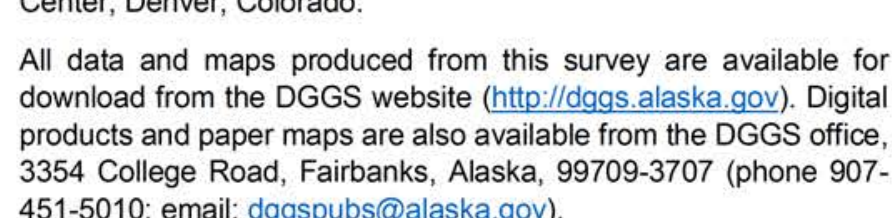




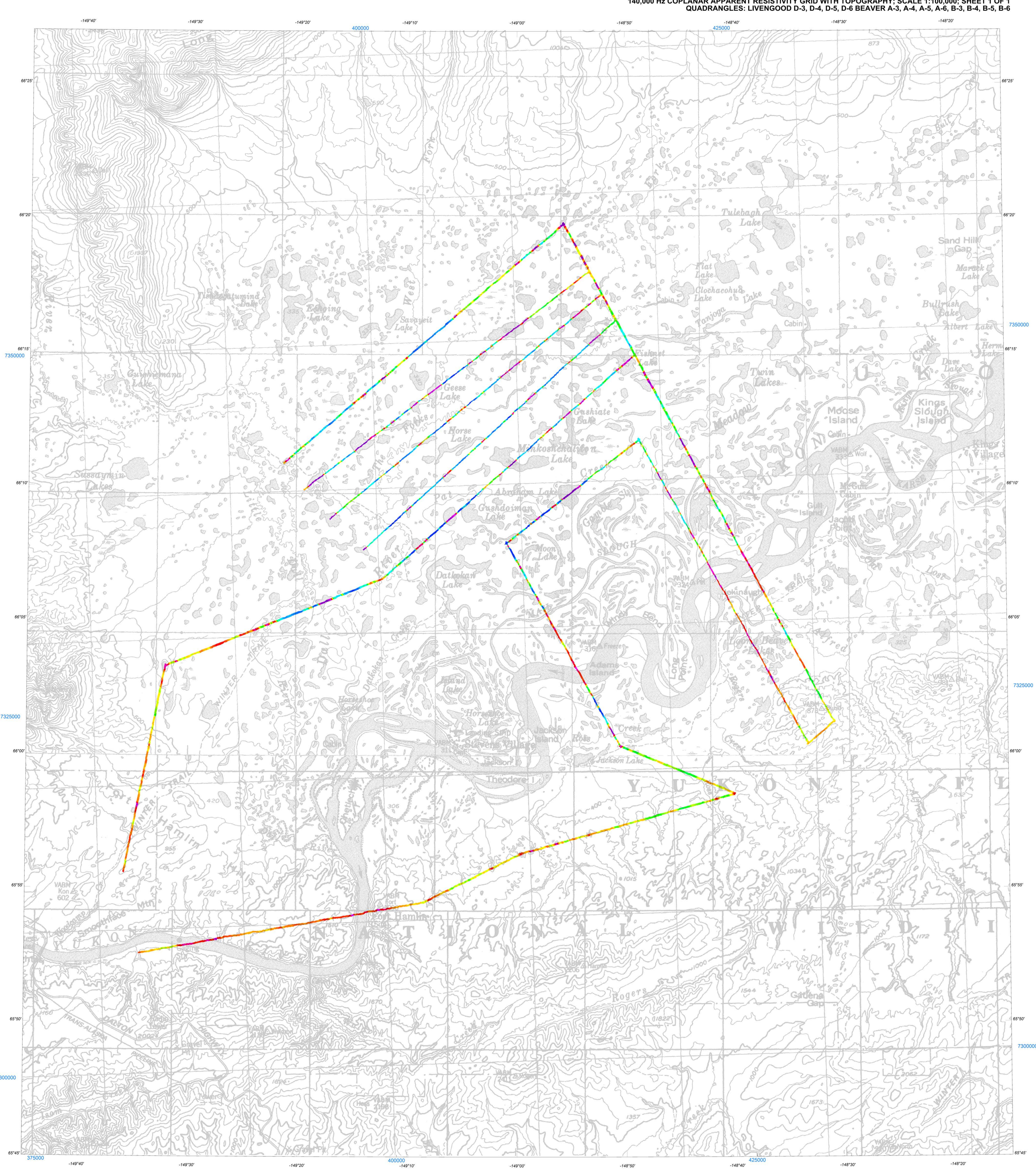

SURVEY LOCATION

AIRBORNE ELECTROMAGNETIC AND MAGNETIC SURVEY WESTERN YUKON FLATS, INTERIOR ALASKA

http://doi.org/10.14509/29683

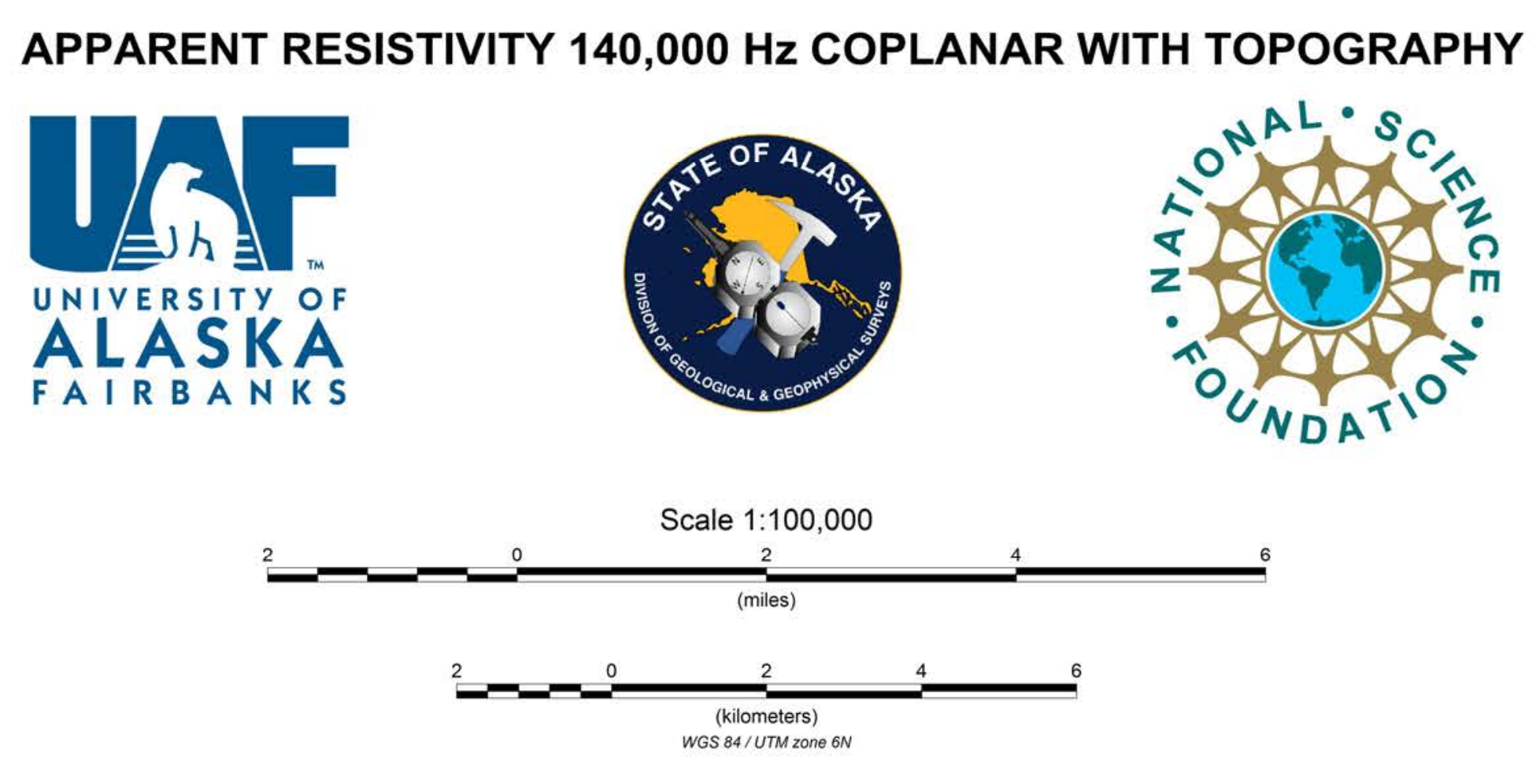

Emond, A.M., Minsley, B.J,, Daanen, R.P., Graham, G.C., and GG Canada Services Ltd.

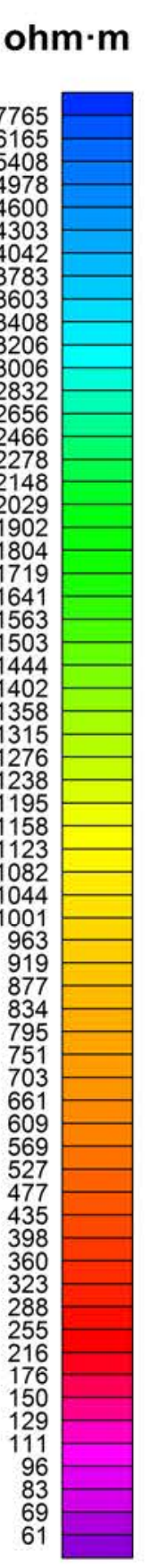

LOCATION MAP

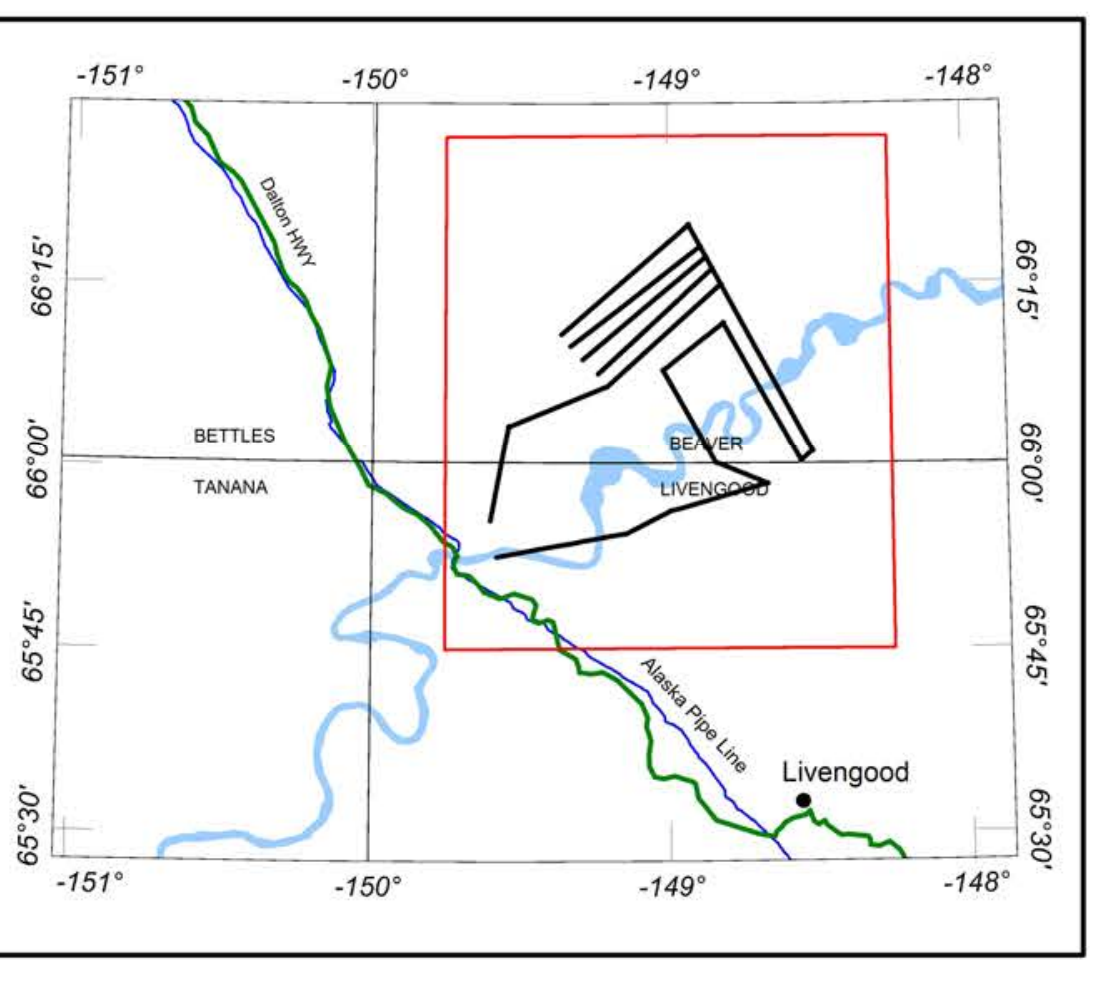

SURVEY YHISTORY

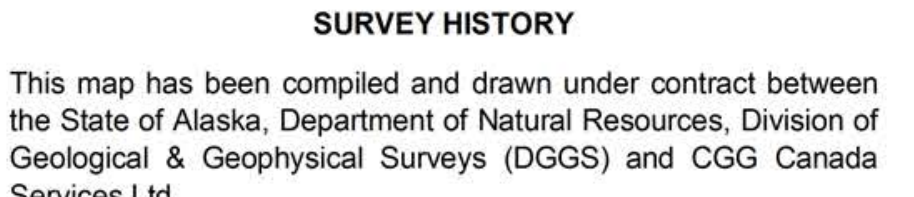

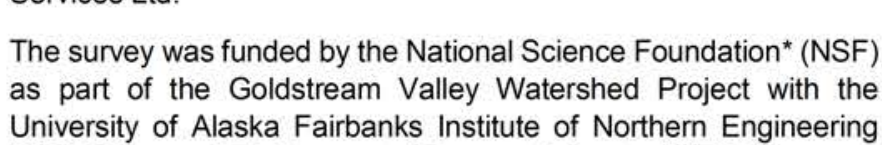

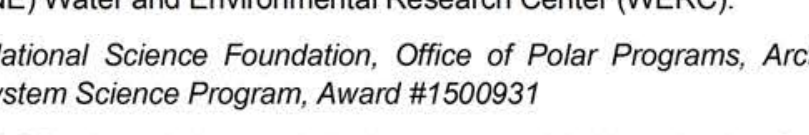

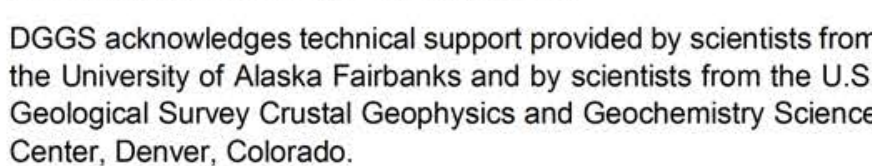

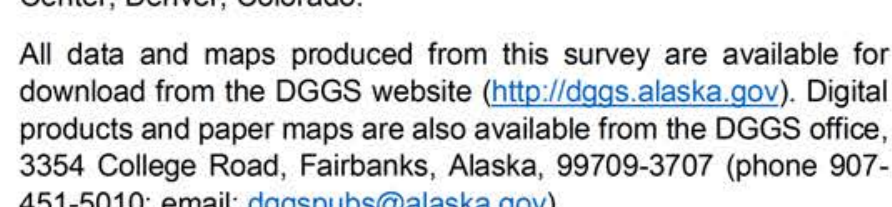




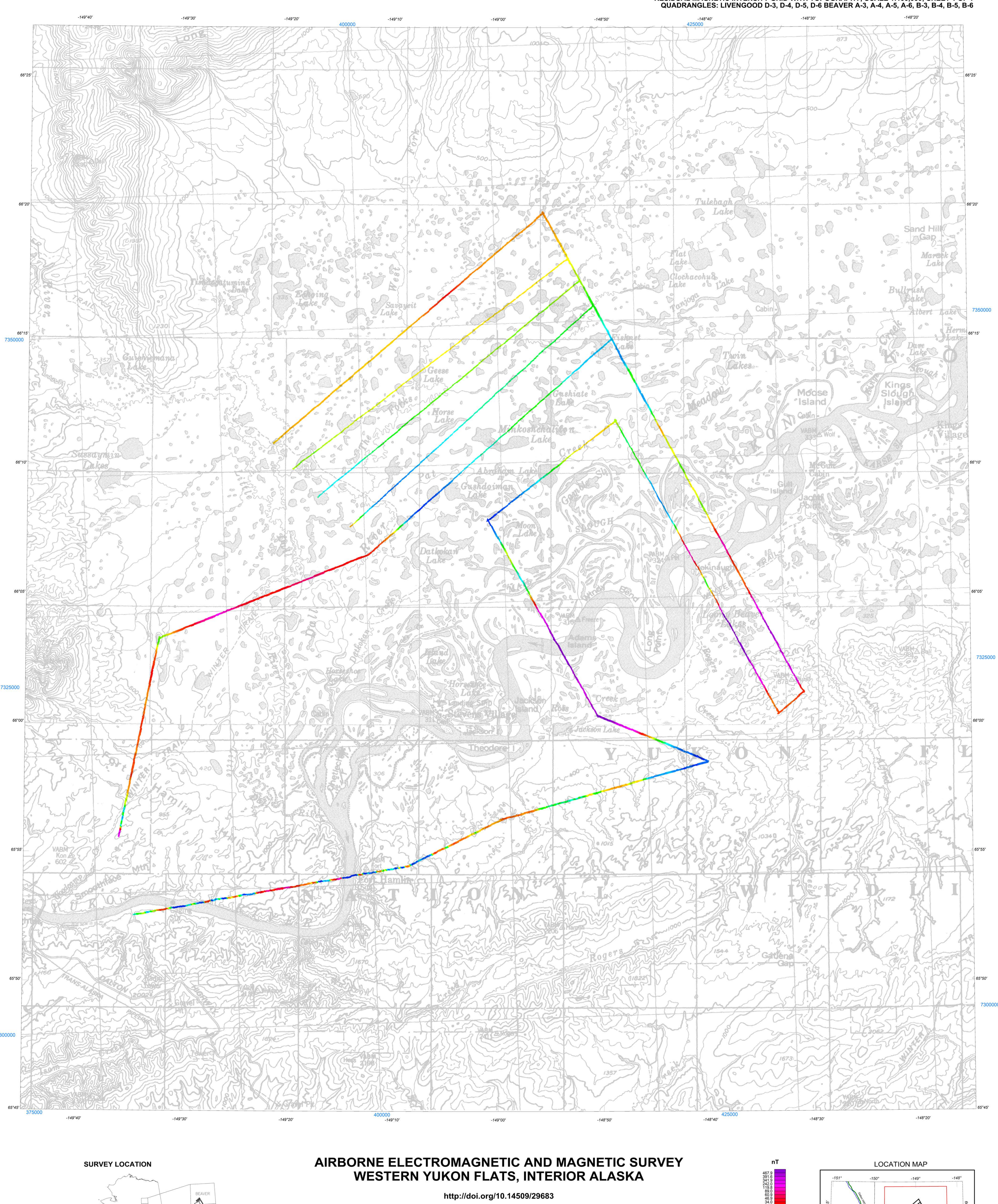

SURVEY LOCATION

AIRBORNE ELECTROMAGNETIC AND MAGNETIC SURVEY WESTERN YUKON FLATS, INTERIOR ALASKA

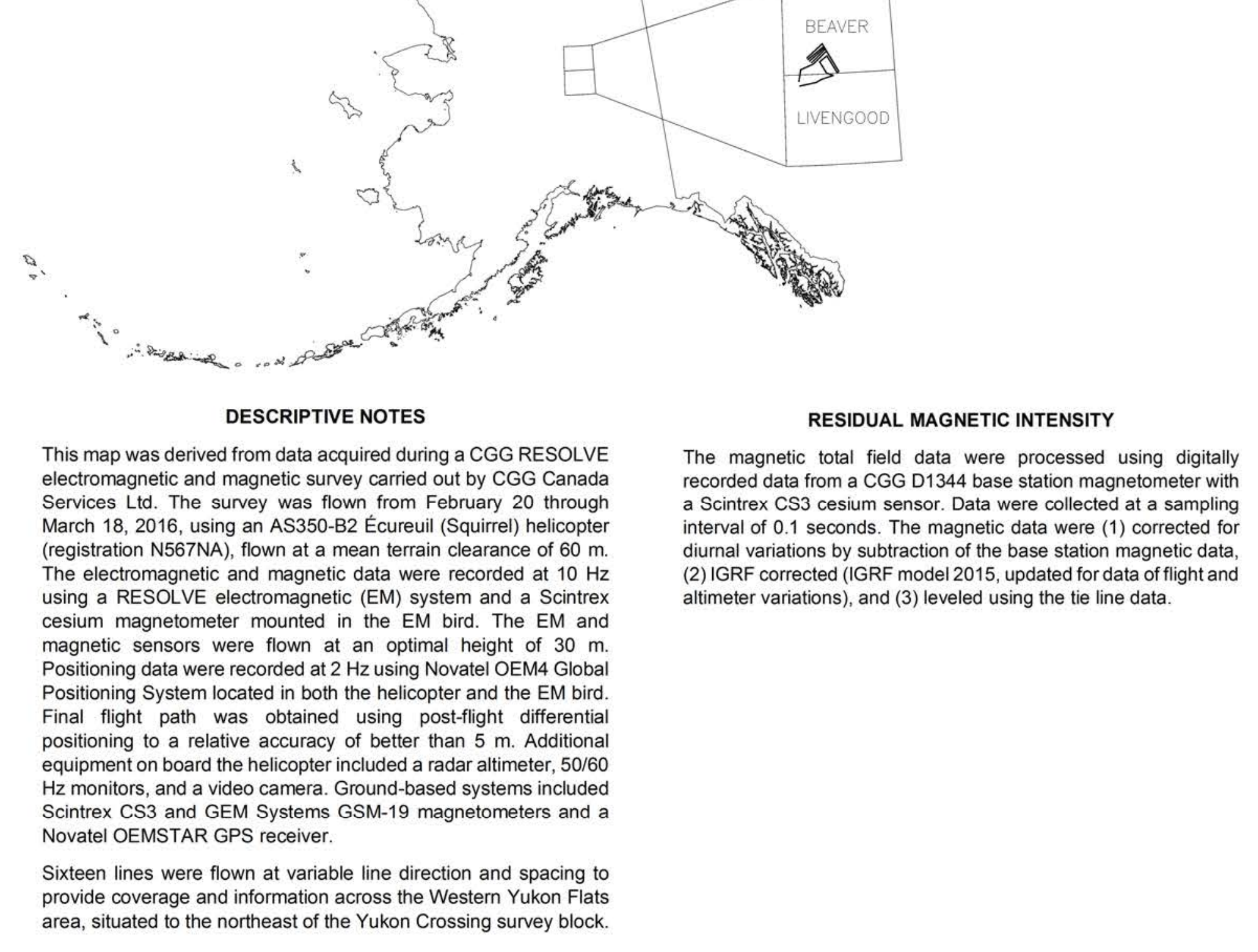

UAF

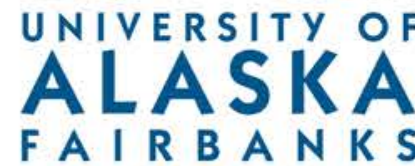

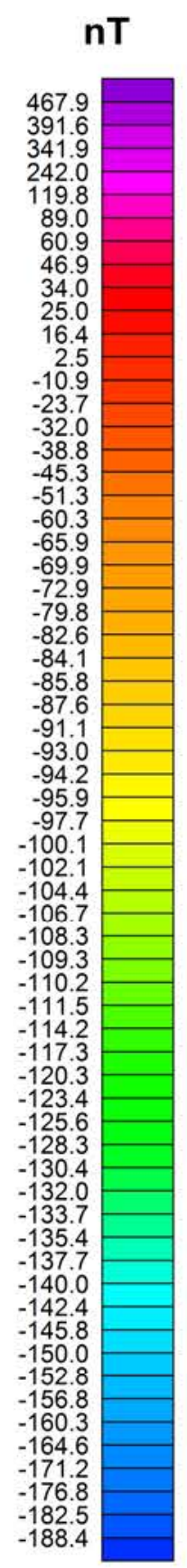

http://doi.org/10.14509/29683

RESIDUAL MAGNETIC INTENSITY WITH TOPOGRAPHY
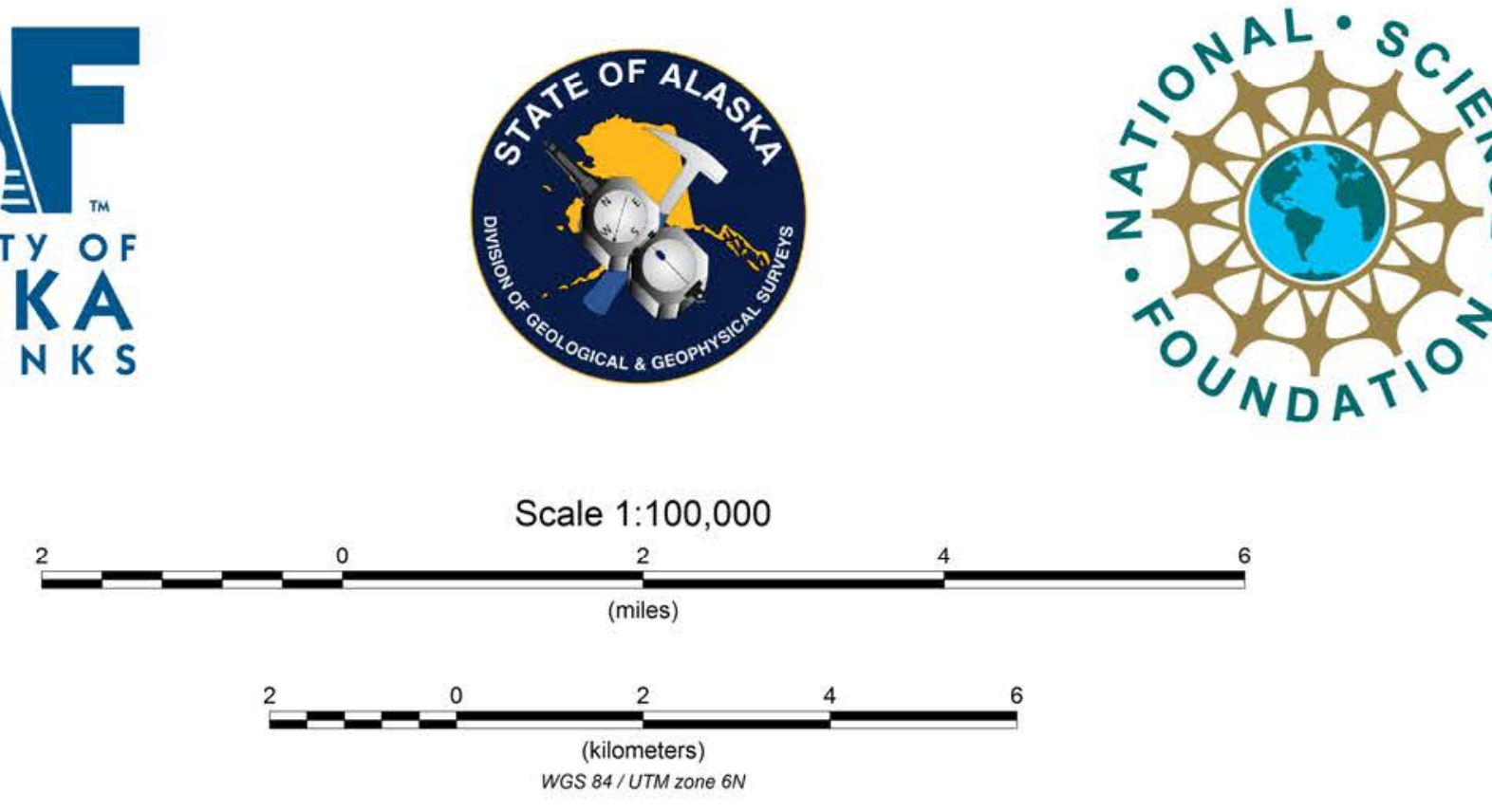

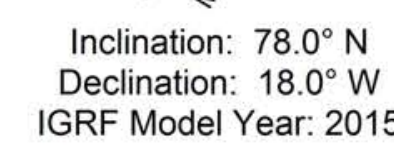

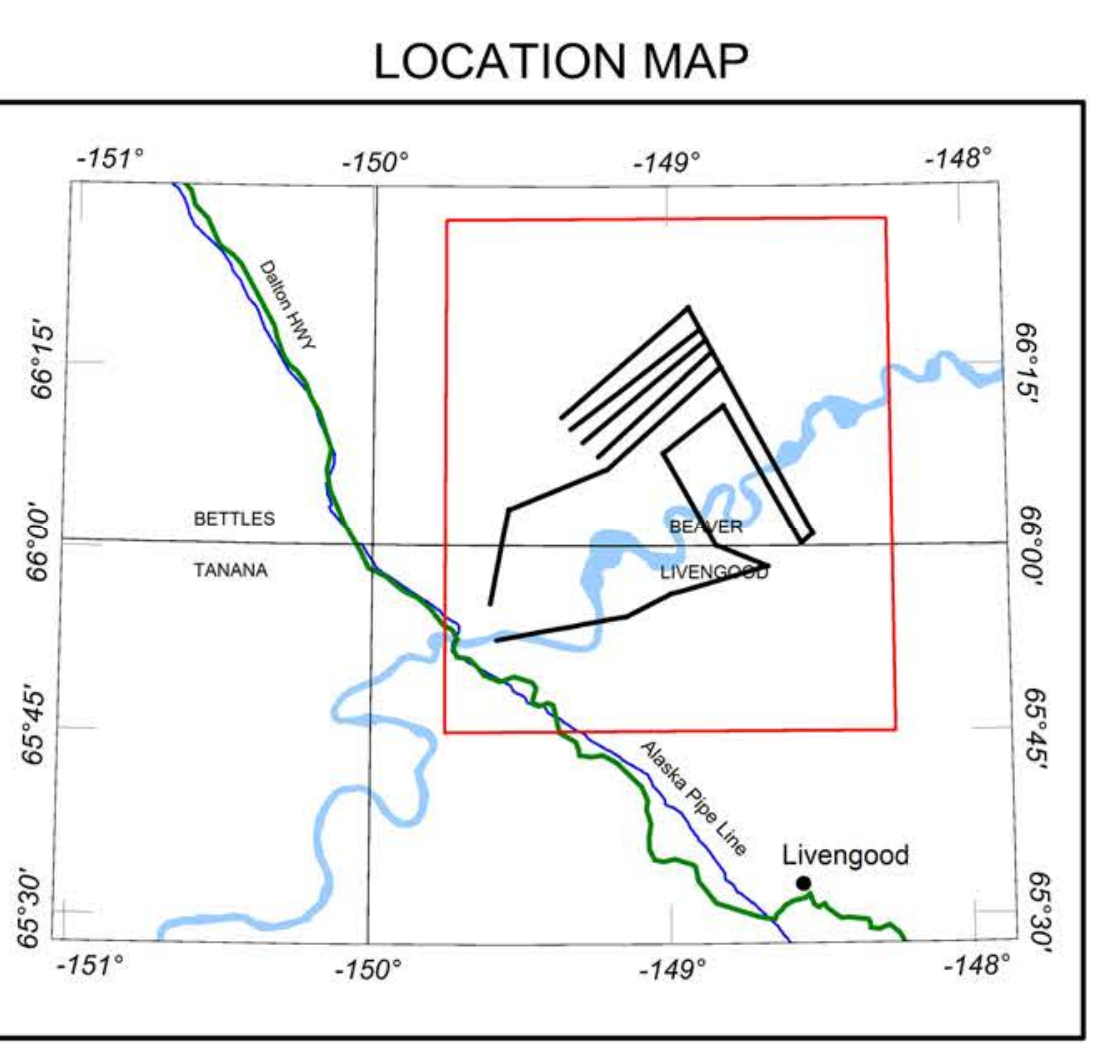

surers

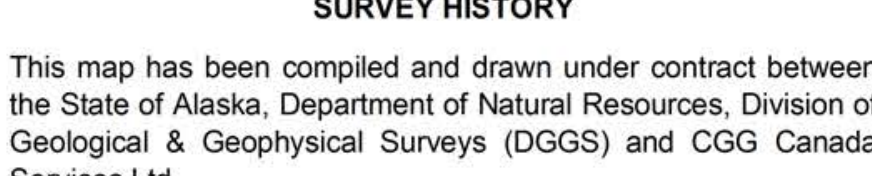

Emond, A.M., Minsley, B.J., Daanen, R.P., Graham, G.C., and CGG Canada Services Ltd. 